Historic, Archive Document

Do not assume content reflects current scientific knowledge, policies, or practices. 



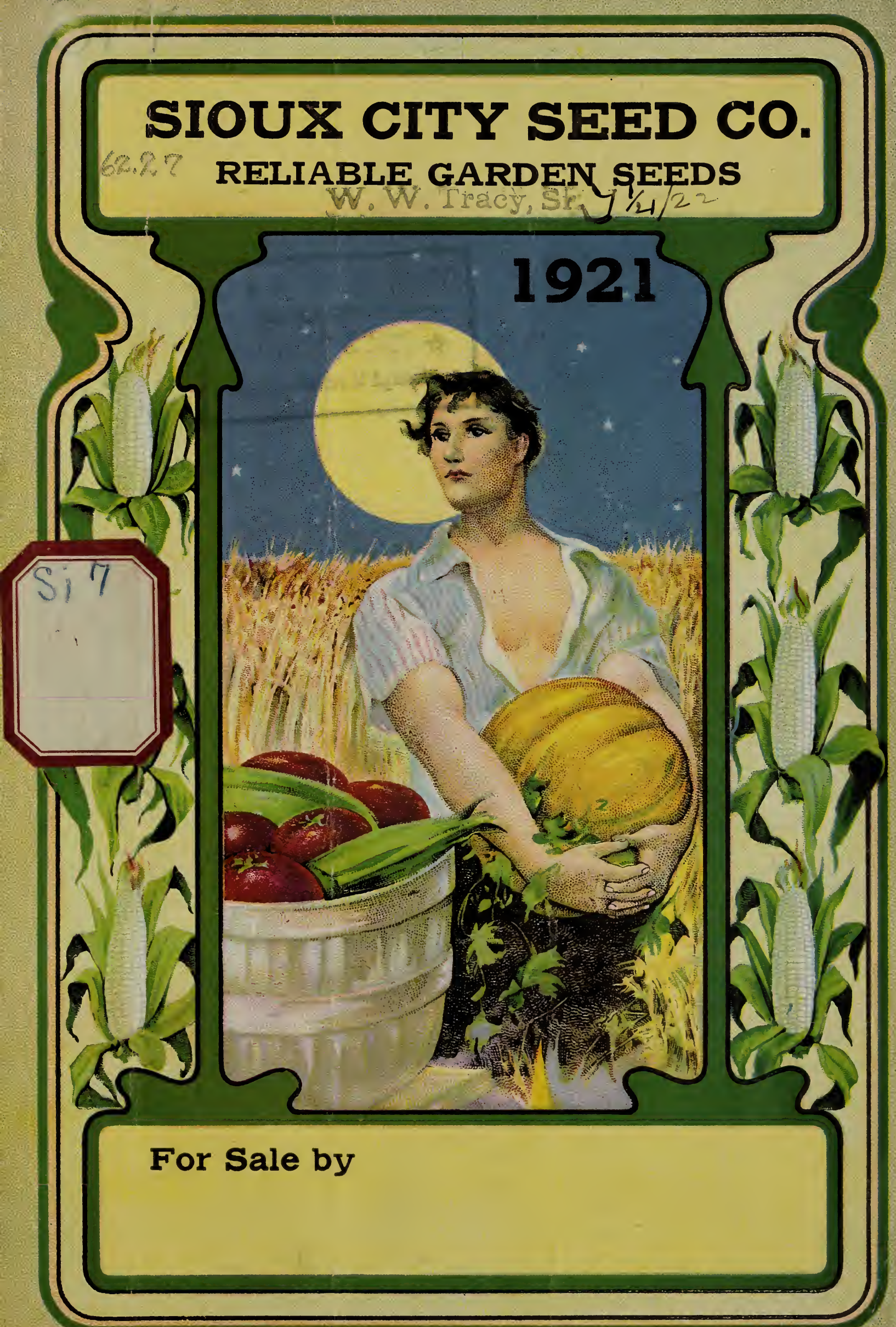





\section{Some Reasons}

Why Seeds

Don't Grow

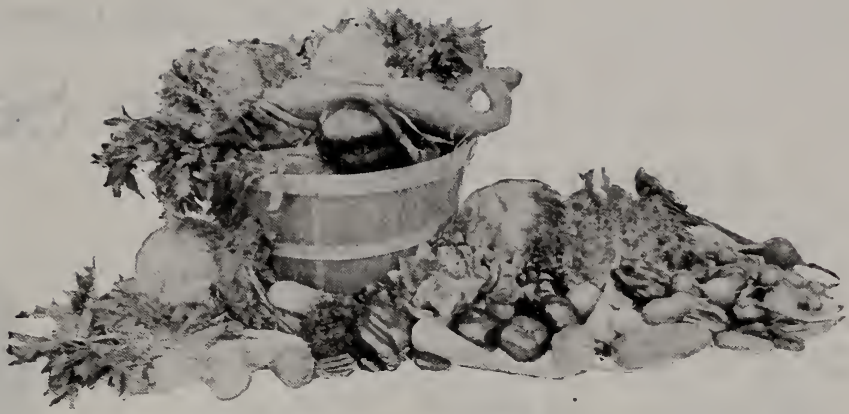

READ CAREFULLY-From time immemorial there has been more or less complaint of garden and flower seeds not growing. We are aware of the fact that there are some poor seeds sold, but we are absolutely certain that very much of the complaint about seeds not growing is not due to poor seeds nearly so much as it is to the seasons and more particularly. the very careless manner in which seeds are planted. The writer of this has been planting seeds from seed boxes for the last forty years, and he wants to testify here that he has had very few failures from the seed not growing and he attributes it largely to the very great care taken in planting. Tive ' $*$ nno' make it too emphatic here, that if seeds are planted in season, soil well prepared and tenderly cared for when they are small and tender, that threefourths of all the complaints of seed failures would be done away with.

\section{Preparation of Soil}

of course, the first thing to do is to get good seeds. our seeds may be depended on, as every variety and kind that we put on the market are tested very carefully. The second thing to do and winich is of the greatest importance, is to put the soil in proper condition. If the soil be wet and heavy, it should be thoroughly drained. There is more danger of too much water than too little. Every man who wants a good garden should prepare the soil in the fall, any time before it is frozen up. Clean off all the rubbish and burn, thoroughly mature the surface and spade under. The freezing of winter will put the soil in prime conciition.

COMMON SEXSE-we are certain that if gardeners and farmers will exercise just good, ordinary common horse senses put their ground in thorough condition, drain well. be careful not to plant too early or too late, putting in those seeds that should go in early, first, and waiting until the season warms up for the other varieties; keep the crust broken after hard beating rains, then two-thirds of the failure in seed planting will be overcome.

TOO DEEP-As a rule nearly all garden seeds, sweet corn, and especially flower seeds, are planted too deep. As a rule, seeds should not be covered more than three or four times their thickness with soil.

FLOWER SEEDS-Flower seeds, as a rule, should not be planted (except Sweet Peas, which should be planted as soon as possible) until the ground is thoroughly warmed and the heavy beating rains of spring are over. Take the utmost pains and thoroughly pulverize and nake exceedingly fine the soil. As a rule, sow the smaller seeds on top of the ground and not in little furrows. Take a box of very fine soil and sift the soil orer them with the hand. It will require but rery little soil to do this.

EARLY PLANTING-This is another fruitful source of seeds not corning up. There are some seeds that can be planted as early as you can get them in the ground, in the spring, with perfect safety, while others must be planted much later. Smooth Peas, Radish, Lettuce, Beet and Onion seed may be planted quite early, while Wrinkled Peas, Beans, all kinds of Vine Seed and Sweet corn should not be planted until the danger of freezing is past, and when the ground has become well warmed up. Vine seeds should not be planted until almost the 1st of May in this Northern latitude. Beans not much before the 20 th of April.

\section{Don't Plant Sweet Corn Over 11/2 Inches Deep}

SWEET COR N-Possibly there are more failures with Sweet Corn than any other one kind of seed and for two very important reasons. First, the Coru is planted too early, when the ground is cold and wet. Sweet Corn will not stand the rough treatment and dampness that Field Corn will stand, because they are soft and spongy, absorb the moisture and rot. Second, Sweet Corn is almost universally planted too deep. It should not be planted, in such seasons as we have been having for two or three years, over an inch or $1 \frac{1 / 2}{2}$ inches deep. Three or four inches, as is often planted, is entirely too deep. of course if the ground be dry, thoroughly drained and warm, it may be planted some deeper. The early rarieties, such as Cory's, White Mexican and Minnesota, may be planted earlier than the later varieties, such as Stowell's Evergreen and Country Gentleman, for they are flintier and hardier and absorb less moisture than the later rarieties. Sweet Corn should be planted closer in hills than Field Corn-and rows closer together, especially the Early varieties-fodder is smaller. We have increased our vield over former years fully 5 per cent by so doing. 


\section{ASPARAGUS}

\section{Vegetable Seeds}

BARR MAMMOTH-Has very large, tender stalks of very light color. Pkt., 5c; oz., 10e; $1 / 4$ lb., 20c.

CONOVER COLOSSAL-The most approved and standard sort; large. Pkt., 5e; oz., 10e; $1 / 4$ 1b., $15 c$.

COLUMBIAN MAMMOTH WHITE-A choice variety; stalks white; good quality. Pkt., 5e; oz., 10c; $1 / 4$ lb., 25c.

ROOTS-Two-year-old, $\$ 1.50$ per $100 ; \$ 10.00$ per 1,000 .

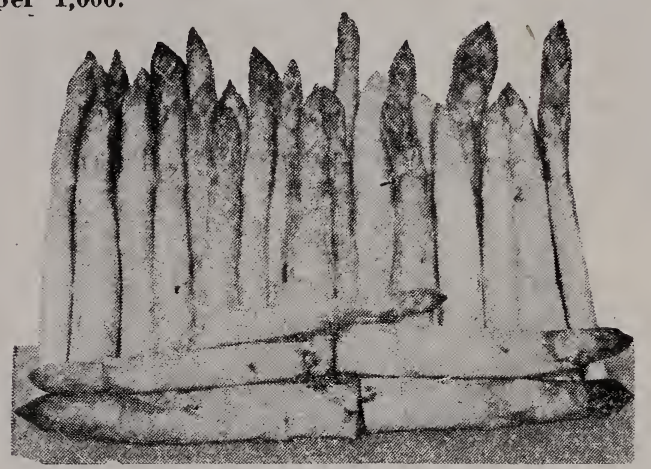

Columbian Mammoth

\section{BEET}

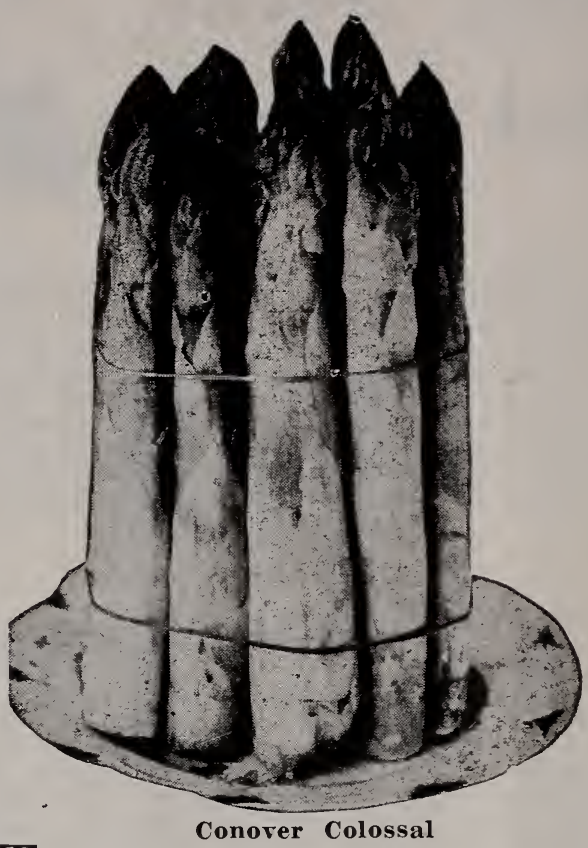

Garden Beets for Table Use Ready For Table Use

CULTURE-Sow as early in the spring as the ground can be worked and every two weeks after for a succession up to the first weeks of July. For general crop sow about the middle of May. The soil should be light sandy loam, well enriched with stable manure and plowed and harrowed until very fine. Sow in drills one foot to fifteen inches apart, and when well up, thin to from four to six inches. The young beets pulled out of the rows are excellent used as Spinach.

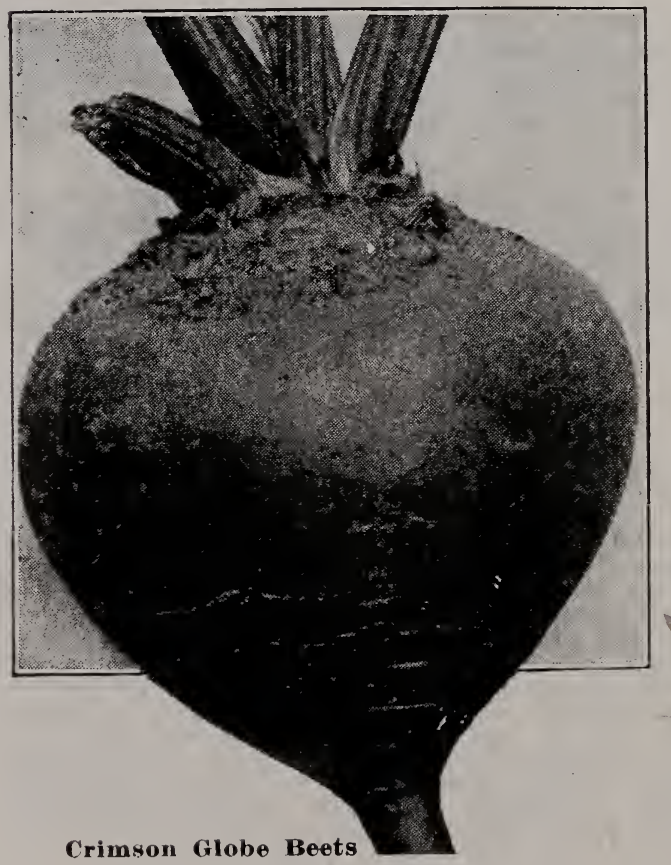

EARLX MODEL-Extremely early; perfect globe, deepest blood red. Oz., 10c; $1 / 41$ 1b., 35̃c.

CROSBY'S EGYPTIAN - An extra early dark blood, round, not flat. Pkt., 5e; oz., $10 \mathrm{c} ; 1 / 4 \mathrm{lb} ., 35 \mathrm{c}$.

CRIMSON GLOBE-Fine shape, smooth, dark red skin, rich deep crimson flesh. Oz., 10c; 1/4 lb., 35c.

DETROIT DARK RED-Very choice deep red; fine shaped beet; see cut. Pkt., 5c; oz., 10c; $1 / 4$ lb., 35c.

DEWING EARLY-Of fine form, flavor and good for market. Oz., 10c; $1 / 4$ lb., 30c.

EARLY BLOOD TURNIP-Dark red and of fine flavor; productive, standard sort. Pkt., 5c; oz., 10c; 1/4 1b., 25c.

EDMAND BLOOD TURNIP-A market gardener's strain of great regularity in shape; deep blood skin and very dark flesh of best quality. Oz., 10c; $1 / 4$ lb., 35c. 
EXTRA EARLY EGYPTIAN-Very early and dark blood color, rather flat. Pkt., 5e; oz., 10c; $1 / 4$ lb., 30c.

EXTRA EARLY ECLIPSE-Very early ; round rooted and dark red; one of the very best. Oz., 10c; 1/4 lb., 30c.

HALF LONG BLOOD-Fine dark strain; distinct variety; smooth and handsome. oz. $10 c ; 1 / 4$ lb., 30c.
LONG SMOOTH BLOOD-A good laté variety; dark red; tender and sweet. Pkt., ó oz., 10c; $1 / 4$ lb., 30c.

SWISS CHARD OR SILVER-Cultivated for its leaves; mid rib, stewed and served as asparagus, best served as Spinach. Pkt., 5e; oz., 10c; $1 / 4$ lb., 30c.

\section{BEETS-Mangel, Wurzel, Sugar, Etc.}

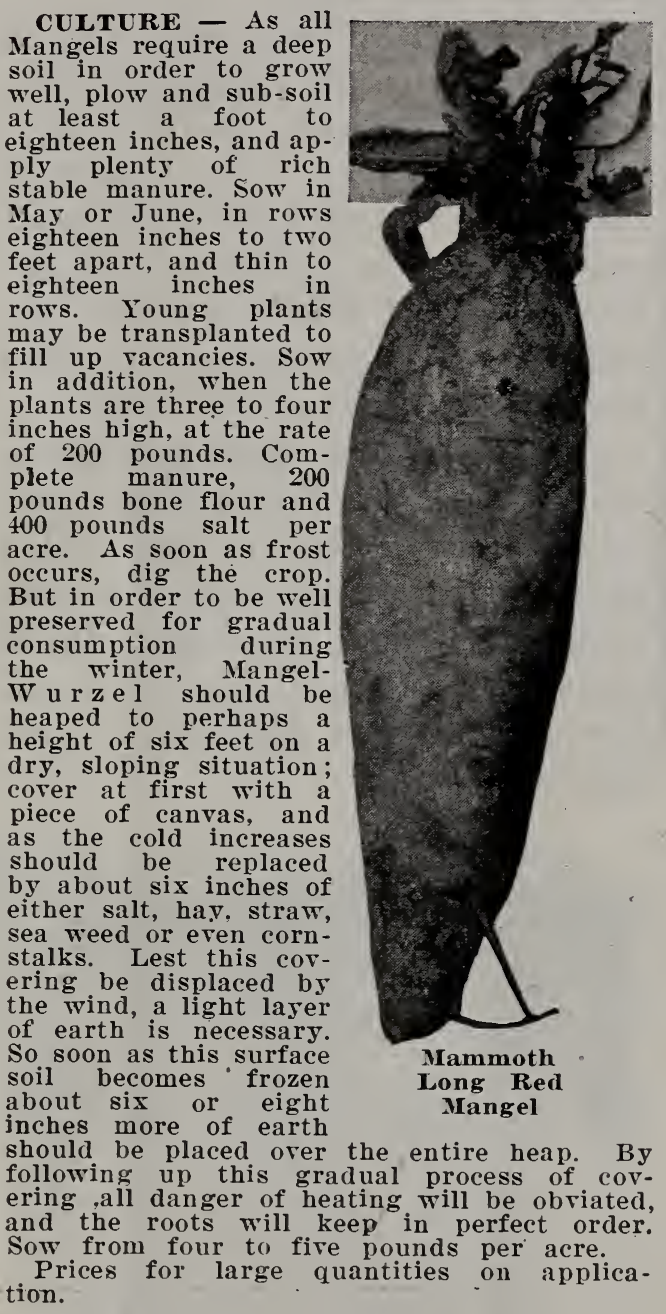

CULTURE - As all soil in order to grow well, plow and sub-soil at least a foot to eighteen inches, and apply plenty of rich stable manure. Sow in May or June, in rows feet apart, and thin to eighteen inches in rows. loung plants plants are three to four inches high, at the rate of 200 pounds. complete manure, 200 pounds bone flour and pounds salt per re. As soon as frost occurs, dig the crop. But in order to be wel for gradual the winter, MangelW urze l should be heaped to perhaps a helght of six feet on dry, sloping situation; cover at first with a as the should be replaced by about six inches of either salt, hav, straw, sea weed or even corncest this corering be displaced by the wind, a light layer of earth is necessary. So soon as this surface soil becomes frozen inches more of earth should be placed over the entire heap By ering, all danger of heating will be obriated, and the roots will keep in perfect order Prices for large quantities on applica-

MAMMOTH LONG RED MANGEL-WURZEL-Very large, selected strain, the largest and finest roots. The standard. Oz., 5c; 1/4 lb., 15e.

LONG YELLOW MANGEL-WURZELGood main crop sort. Oz., 5c; 1/4 1b., 20c.

ORANGE GLOBE MANGEL-WURZEIOf distinct shape; one of the most productive, hardy, vigorous. Oz., 5e; 1/4 lb., 20c.

GOLDEN TANKARD MANGEL-IVURZEL -A bright yellow; handsome and sweet, and very productive; tops small, roots large. Oz., 5c; 1/4 1b., 20c.

RED GLOBE MANGEL-WURZEL-Similar to the Yellow Globe; productive. Oz., 10e; $1 / 4$ lb., 30c.

CANE'S SCGAR-For sugar making! or stock feed. Oz., 10c; 1/4 1b., 25c.

WHITE SUGAR BEET-Grows to a large size, and is useful for making sugar as well as for stock feeding. Oz., 10c; $1 / 4$ 1b., 30c.

VILMORIN IMPROVED SUGAR-A much improved strain of the preceding; very valuable as a sugar producing beet. Oz., 10c; $1 / 4$ 1b., 25̃c.

KLEIN WANZLEBEN-Larger than Vilmorin; good sugar beet; very hardy. oz., 10e; 1/4 1b., 25̃e.

GIANT FEEDING SUGAR-This unites the large size of the Mangel with the greater feeding ralue of the Sugar Beet. The roots are always regular and uniform, broad at the top with a full and slightly tapering shoulder. Oz., 5e; 1/4 1b., 15e.

\section{BEANS}

\section{Bush Beans}

CULTURE-Beans are easily frost killed, so plant them at corn planting time on light, dry land. Cold, wet weather will rot the seed in the ground and fresh wanure causes a rank growth of vine with a lack of pods. If hand cultivated beans can be orilled in poor soil as close as eighteen inches, but in rich soil with horse cultivation, thirty inches is required. Drill six beans to a foot and cover one inch deep, or plant four beans to the hill eighteen by twenty-four inches apart. One quart of seed should plant 200 feet and five pecks plant an acre. Plant every third week for a succession up till August 1st in the latitude of Sioux City. Pick beans before the bulge of seed appears and pick beans clean to continue the plants bearing. Give beans shallow cultivation and do not till the soil when the plant is in bloom or the plant in self defense will drop its blossoms. To cultivate when wet is to invite rust. 


\section{BEANS-Continued}

\section{Royal Round Pod Purple Wax Bean}

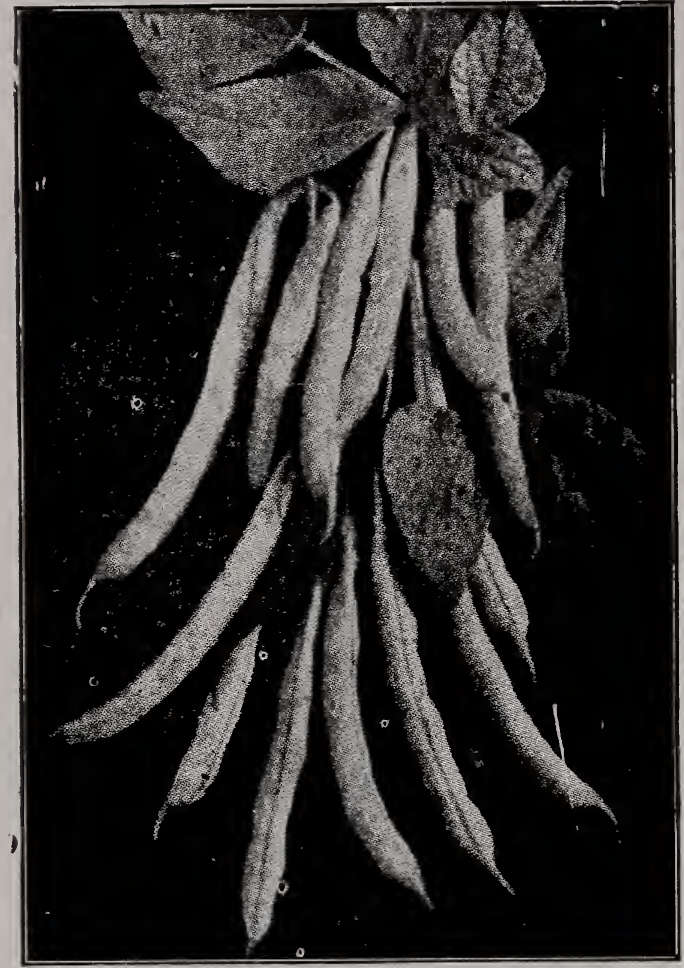

Roýal Round Pod Purple Wax

Sioux City, Iowa.

Gents: I planted this spring a row of your new Royal. Purple Wax Beans. I consider it the best bean I ever ate; quality is unsurpassed; perfectly stringless; round pod, very early.

Respectfully

MRS. EVA R. CUMMINGS.

Sioux City Seed Co., Sioux City, Iowa.

Dear Sirs: I have had your new wax bean, the Royal Purple Round Pod Wax, growing on my trial ground this season and I have been much pleased with it. : It is of high quality and has the much desired round, straight, fleshy pod. I believe that it will fill the same place among Wax Beans that Burpee's Stringless does among the Green Pods. You certainly have a good thing in your bean and I hope you will push it extensively.

Yours Truly,

H. $\mathrm{F}$.

\section{Dwarf Wax Beans}

Ready for Use in 35 to 40 Days

DAVIS WhITE WAX-Very hardy, productive, long pods, very handsome, rustless, fine shipper, best canner; in all points the best wax. Pkt., 15c; 1b., 35c.

GOLDEN WAX-Best known wax bean : very early, fine podded. Pkt., 15c; 1b., 30c.

BLACK WAX-Has great merit, very tender and best quality. Pkt., 15c; lb., 30c. Ask for Special Prices on Quantity

\section{Stringless Wax Bean}

This new bean, introduced by us, promises to be a great accession to the market gardeners.

Description-Plant large, without runners; generally drooping with fruit laden branches and spreading when full grown. The season is early; the leaf is large, medium green; wide across leaflets; pods are very round and yellow in color; very brittle; stringless; without fibre and unsurpassed in quality. Owing to its being a prolific Bean and as tender as the Crystal White Wax, it will be much in demand by the market gardeners, or those wanting a firstclass, round pod, wax bean. In 35 years of experience as growers, we have never found anything to com. pare with it.

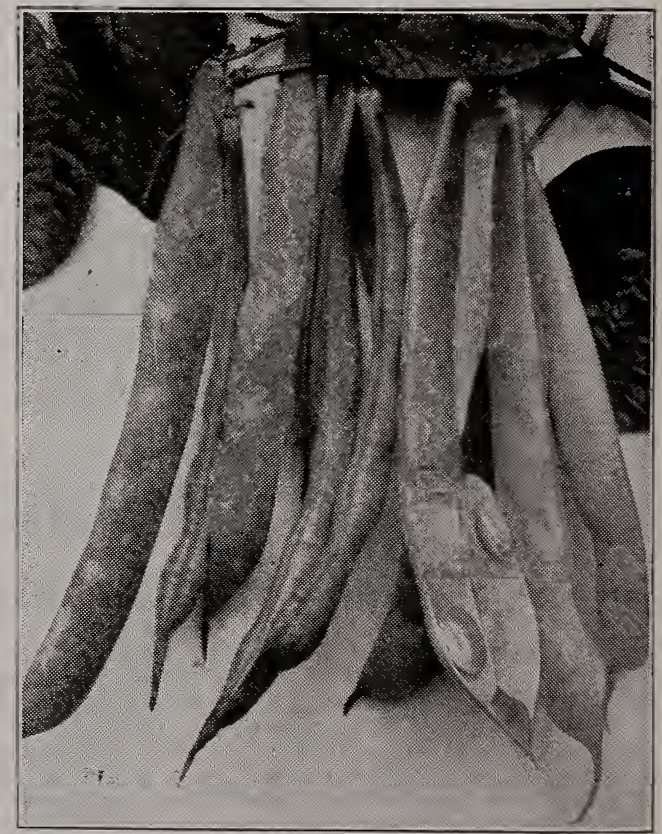

Golden Wax 


\section{BEANS-Continued}

ROYAL PURPLE WAX-See description, page 2. Pkt., 15c; lb., 30c.

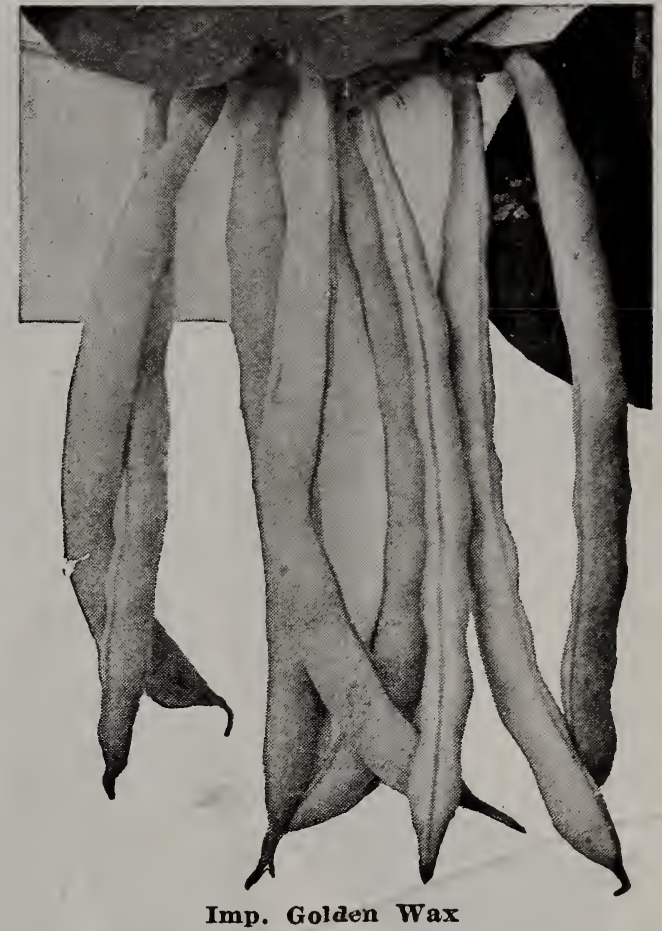

IMPROVED PROLIFIC BLACK WAXVery early and prolific. The pods are round, full, stringless and of fine quality. Pkt., 15e; lb., 30c.

CHALLENGE BLACK WAX-An extra early strain of the Dwarf Black Wax. Pkt., $15 \mathrm{c} ; 1 \mathrm{lb} ., 30 \mathrm{c}$.

DETROIT WAX-Very much like Golden Wax, but less liable to rust. Pkt., 15c; lb., 30c.

FLAGEOLET WAX-Flat, yellow, stringless pods of great length and breadth. Exceedingly productive. Pkt., 15c; lb., 30c.

GRINNELL'S IMPROVED GOLDEN WAX -Very early; round golden pods. .Pkt., 15c; 1b., 30c.

CURRIE'S RUST-PROOF WAX-Vigorous and hardy; productive. Pkt., 15c; lb., 30c.

REFUGEE WAX-A perfect Refugee with long, round, yellow wax pods; suitable for early or late sowing, and an immense yielder. Pkt., 15c; lb., 30c.

WARDWELL KIDNEY WAX-Extra early; purely wax, pods long, flat and remarkably free from rust. Pkt., 15c; 1b., 35c.

\section{Dwarf or Snap Bean}

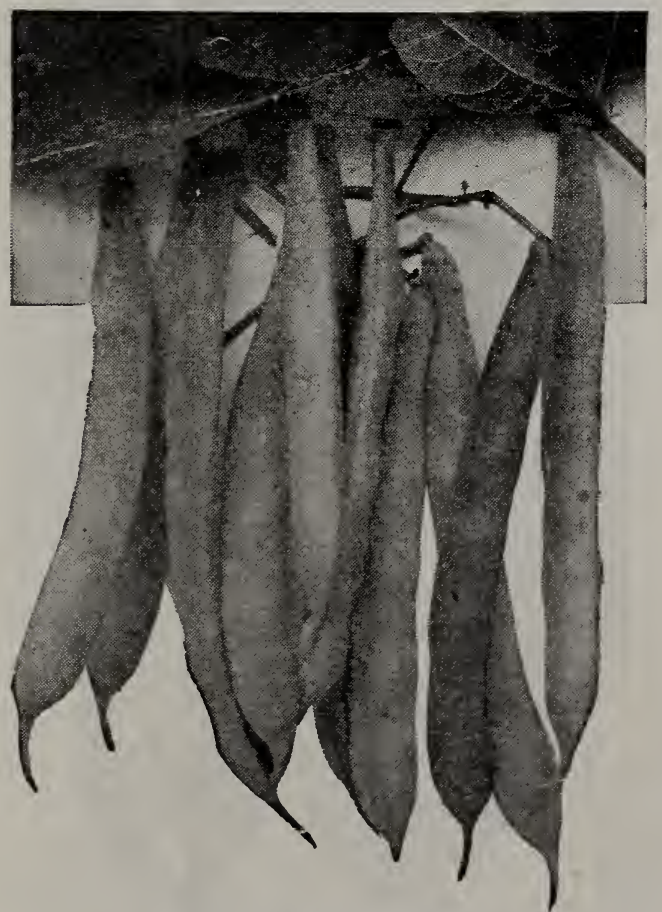

Burpee's Stringless Green Pod
BURPEE'S STRINGLESS GREEN PODThis new bean produces a vine similar to Red Valentine, but develops pods to edible condition two to three days earlier than Valentine. This advances the Stringless Green Pod to the first rank among table beans. Pods are stringless-absolutely so -the pods breaking as short and free as pipe stems; enormously productive. Pkt., 15c; 1b., 30c.

DWARF HORTICULTURAL-Late and productive; fine either shelled or green. Pkt., 15c; 1b., 30c.

EARLY MOHAWK-Long, flat and straight pods; very hardy. Pkt., 15c; lb., 25c.

EXTRA EARLY RED VALENTINE-Early strain of this popular round pod bean, nothing superior to this in snaps among the green podded sorts; many prefer to Wax varieties. Pkt., 15c; lb., 25c.

TENNESSEE GREEN POD-Pods large, fine flavor, popular in South. Pkt., 15c; lb., 30c.

GIANT STRINGLESS-Similar to Burpee's Stringless; lighter in color; hardy, and highest quality. Pkt., 15c; 1b., 30c. 


\section{BEANS-Continued}

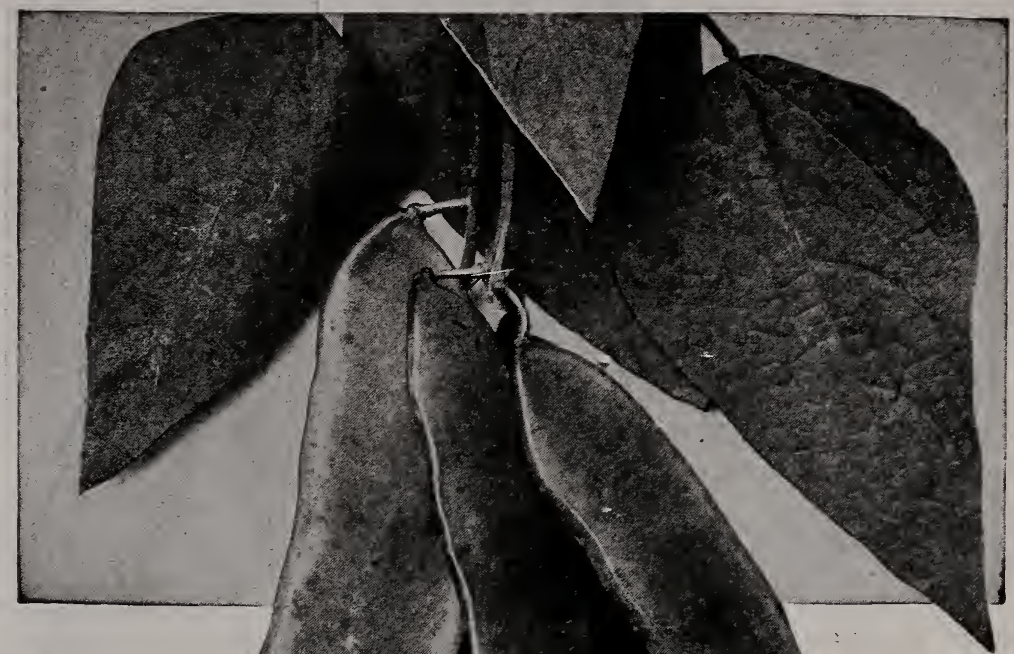

ROUND, EA R $\mathbf{Y}$ YELLOW SIX WEEKS -Resembles the Mohawk; sable in color flat pods; a popular one. Pkt., 15c; lb. $25 c$.

LONG YELLOW SIX WEEKS-Early ; the leading market sort: full; flat, green pods; good quality. Pkt., 15c lb., 25c.

LOW'S CHAMPION -A very productive variety, with perfectly stringless, large green flat pods. Pkt., 15c; lb., 30e.

REFCGEE OR 1,000TO-1-Medium to late; very productive and tender, and largely grown for main crop round pod. Pkt., 15e; lb., 30c.

PROLIFIC TREE(Navy) - The most prolific bean known; bean not large, but fine shape, cooks easily. Lb., 25c.

WHITE NAVY OR PEA BEAN -Seed white; nearly round. Lb., 25c.

WHITE KIDNEY OR ROYAT DWARF-Fine winter shell bean. Lb., 25c.

BURPEE'S BCSH LIMA-A bush form of the large Pole Lima, the beans being large and flat, like those of that variet $y$. It is very productive and its dwarf character is well established. Pkt., 15c; lb., 40c.

Lima, the beans being large and
flat, like those of that variety
It is very productive and it
dwarf character is well estab
lished. Pkt., 15c; lb., 40c.
HEYDERSON'S BUSH LIMA OR SIEYAProductive; a very early bean. Pkt., 15c; lb. 35c.

DREER'S BUSH-Immensely productive; Fordhook Lima may be used as a shell bean or snap bean broad, flat pods. Pkt., 15c; 1b., 45c.

FORDHOOK BUSH LIMA-Early; -very productive, best quality. Pkt., 15c; lb., 45e.

CULTURE-The pole bean climbs, sometimes needing a little training over any support given it. A good practice is to set firmly in the ground every three or four feet each way, poles that are, when set, about six feet high. Some time after bunch beans are planted, six or eight pole beans are planted one inch deep near the base of each stake and later thinned to three or four plants to the pole. One-half bushel of pole beans generously plants an acre and one pint plants one hundred hills. The pole bean bearş over a longer period than the bunch bean and is generally considered of superior quality, but it requires moré labor, longer time to mature, and is more sensitive to adverse climatic and soil conditions. Note that the vine turns only one way around its support.

When too old for use as a green snap bean, use any bean shelled, or still later, when it is hard and dry, it remains equally serviceable.

Ready for Use in 70 to 90 Days

GOLDEN CARMINE PODDED HORTICULTURAL-In this new strain we have a wonderful, robust grower. The pods are large, stringless, bright golden color when very young. As they approach full size, they are mottled and streaked with an unusually bright carmine color on the golden, which gives the pods when ready for market, a beautiful and attractive appearance. Pkt., 15c; lb., 35̃c.

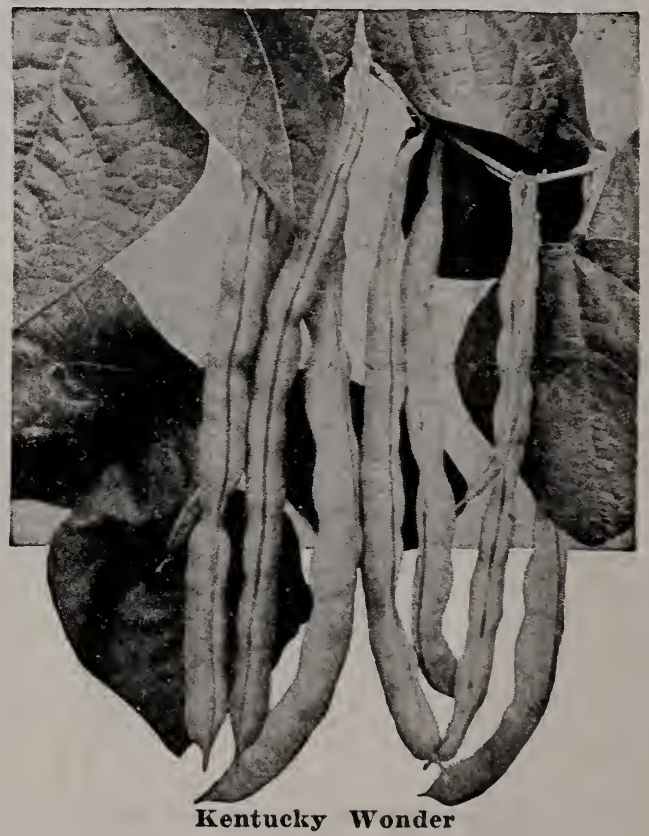


DUTCH CASE KNIFE-Pods long, green and flat; can be either snapped or shelled. Pkt., 15e; 1b., 30e.

SCARLET RUNNER-A popular English Pole Bean; very ornamental. Pkt., 15c; lb., 30c.

WHITE CREASE BACK-Long, round, stringless pod; fleshy and tender. Pkt., 15c; lb., 30c.

WHITE KENTUCKY WONDER-Very fleshy and tender; stringless; of high quality. Pkt., 15c; lb., 30c.

KENTUCKY WONDER (Old Homestead) -Pods green, very long, very prolific. Pkt. $15 \mathrm{c} ; 1 \mathrm{b.}, 30 \mathrm{c}$.

GOLDEN CLUSTER-Early, productire golden wax pods six to eight inches long. Pkt., 15c; lb., 40c.

LAZY WIFE-Great favorite; pod from four to six inches long, stringless, rich, buttery flaror; beans are white and make a fine shell bean; pods remain green and tender long. Pkt., 15c; lb., 40c.

HORTICULTURAL OR SPECKLED CRANBERRY-Showy, excellent either as a snap or shell bean. Pkt., 15c; lb., 35c.

SPECKLED CUT-SHORT OR CORN HILI-Used for planting among corn; one of the best. Pkt., 15c; lb., 35c.

MISSOURI WONDER-Late, very productive; disease resisting. lb., 30c.

\section{Pole Lima}

LARGE WHITE LIMA-Largely " grown and highly esteemed. Pkt., 15c; 1b., 40c.

KING OF THE GARDEN LMA-Large in pod and bean; productire. Pkt., 15c; lb., ine.

DREER LIMA-Thick and of fine quality; early variety. Pkt., 15̃c; lb., 40c.

EARLY JERSEY HIMA-A few days earlier than the large Lima. Pkt., 15c; lb. 35 c.

HORTICULTURAL LIMA--A cross between the Horticultural and Dreer Lima. It matures much earlier than the Lima. Pkt. $15 \mathrm{c} ; 1 \mathrm{lb} ., 35 \mathrm{c}$

\section{Ask for Quantity Prices \\ BROCCOLI}

CULTCRE--Sor early sorts as soon as the ground ran be worked in the spring, in shallow drills, drawn three or four inches apart. Plant out two feet apart each way when the plants are about four inches high. Cultirate the same as cabbage, in rich soil. Use the same remedy for insect attacks as are recommended for cabbage. The following are sorts best adapted to this climate, and the only ones which succeed generally; they are excellent and deserve much wider culture than is usual in this country.

EARLY WHITE CAPE-Best flavor: very hardy; small. Pkt., 5c; oz., 30c.

FARLY WALCHEREN-Late variety. Pkt., 5c; oz., 40c.

EARLY FUKPLE CAPE-The very best : large. Pkt., 5c; oz., 30c.

\section{BRUSSELS SPROUTS}

CULTURE-Sow in May in the same manner as Cauliflower and transplant in July, one foot apart, in the rows, which should be one and one-half feet apart. In gardens, both large and small, Brussels
Sprouts are, without exception, the very best winter vegetable that can be grown. The real sprout is not much larger than a marble, and as firm and hard almost as the stalk itself. These are the sorts which cooks prefer. They strip off the outer covering, cook them whole, and serre them up artistically in that fashion. When cooked through and no more, such Sprouts melt in the mouth like the tenderest Cauliflower, and are equally as good.

IMPROVED HALF DWARF-The rery best and surest strains. Pkt., 5c; oz., 20c; 1/4 lb., 60c.

IMPROVED DWARF-Compact heads of fine quality. Pkt., 5c; oz., 20c; $1 / 4$ lb., 60c.

\section{GARROTS}

Ready for Table in 60 to 80 Days.

EARLY HORN-Very early variety, small root; excellent flavor. Pkt., 5c; oz., 10c; $1 / 4$ 1b., 35c.

FRENCH EARLY FORCING-Tender and fine; best for early and late crops and frames. Pkt., 5c; oz., 10c; $1 / 4$ lb., 40c.

HALF-LONG STUMP ROOTED, CHANTENAY STRAIN-Style of Nantes; has broader shoulder. Pkt., 5c; oz., 10c; 1/4 lb. 30c.

HALF LONG DANVERS-Thick, of good quality and exceedingly productive, Pkt., 5c; oz., 10c; $1 / 4$ lb., 25c.

LARGE WHITE BELGIAN-Very large : excellent stock Carrot. Pkt., 5c; oz., 10c; 1/4 lb., 25e.

LARGE. YELLOW BELGIAN-V e r $y$ large; excellent stock Carrot. Pkt., 5c; oz., $10 \mathrm{c} ; 1 / 41 \mathrm{lb} ., 25 \mathrm{c}$.

OXHEAR'T OR HALF-LOYG GUERANDE--This is one of the most raluable of recent introduction, either for family or market; most beautiful shape and rich orange color. Pkt., 5c; oz., 10c; 1/4 1b., 30c.

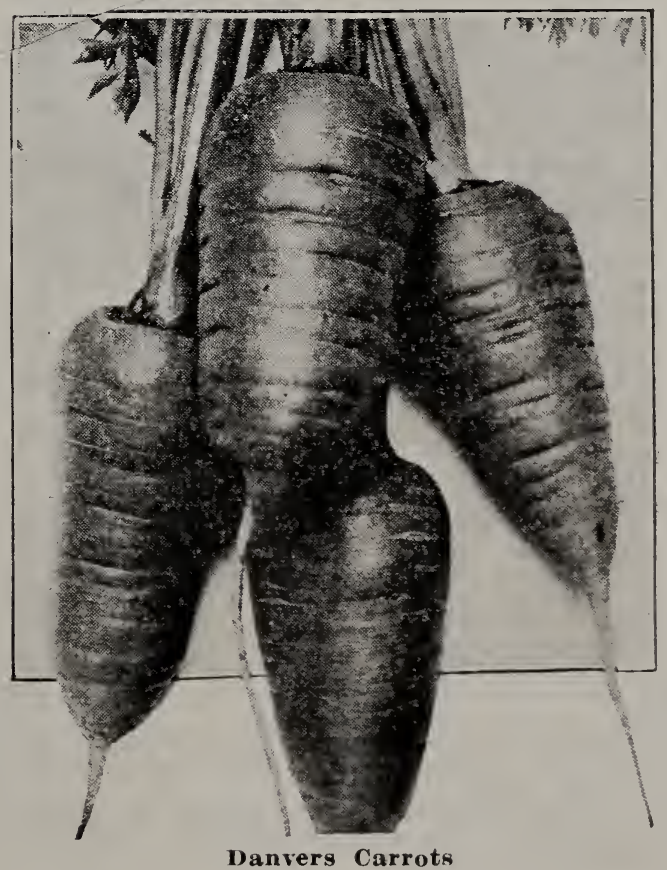





\section{CAULIFLOWER}

CULTURE-This is the same as for Cabbage, except that extra manure and plenty of water will pay upon this. If the soil be dry, water frequently, and if the plants could have a heary mulch of hay or straw, it would keep the soil moist and the plants would not suffer from drouth. The early kinds should be strong enough to plant out not later than the middle of April; the late kinds may be planted out same time as for Cabbage. To destroy the Cauliflower maggot, it is recommended to take one ounce of sulphur of potassium and dissolve it in one gallon of water. Heat the liquid to about 100 degrees, take a large spoon, or something that will hold the 100 th part of a gallon, and pour the liquid against the stalk of the plant just above the ground.
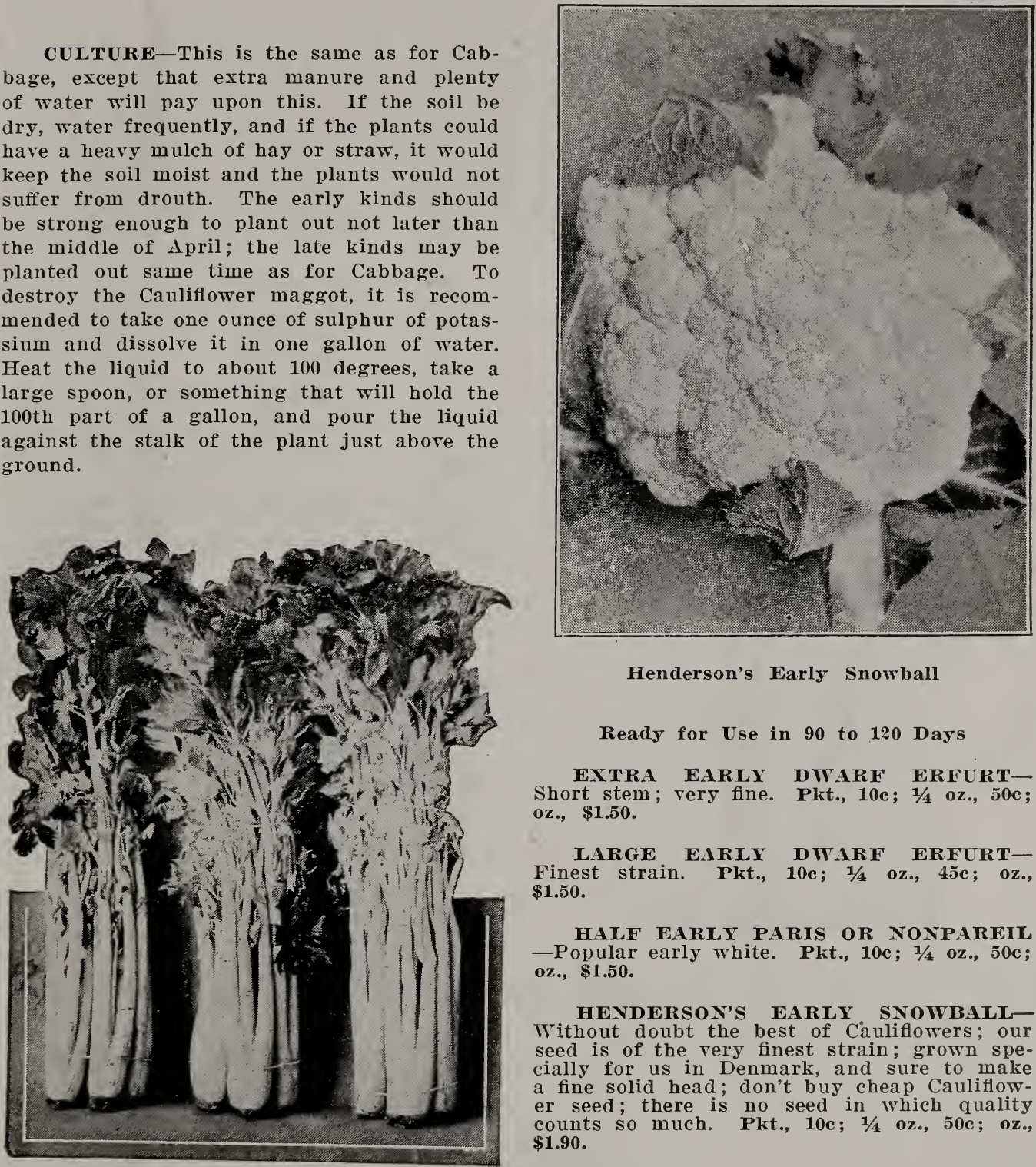

Henderson's Early Snowball

Ready for Use in 90 to 120 Days

EXTRA EARLY DWARF ERFURTShort stem; very fine. Pkt., 10c; $1 / 4$ oz., 50c; oz., $\$ 1.50$

\section{LARGE EARLY DWARF ERFURT- Finest strain. Pkt., 10c; 1/4 oz., 45c; oz.,} $\$ 1.50$.

HALF EARLY PARIS OR NONPAREIL - Popular early white. Pkt., 10c; 1/4 oz., 50c; oz., \$1.50.

HENDERSON'S EARLY SNOWBALLWithout doubt the best of Cauliflowers; our seed is of the very finest strain; grown specially for us in Denmark, and sure to make a fine solid head; don't buy cheap Cauliflower seed; there is no seed in which quality counts so much. Pkt., 10c; 1/4 oz., 50c; oz., $\$ 1.90$.

Golden Self-Blanching

\section{CELERY}

CLLTURE-Sow the seed in a light, rich, dry border as early as the ground can be worked, in drills eight or ten inches apart, and cover the seeds about a quarter of an inch deep, rolling or treading them in if the ground be dry. When fairly out of the seed leaf they may be transplanted to another bed, or they may be thinned out in beds or trenches. The bed should be kept well weeded, and an occasional soaking with water in dry weather will do the plants good. Early in July at the north, a month or six weeks later in the southern states, is the proper time to set the plants out in beds or trenches. Press the soil firmly against the roots. In the garden the better way is to set the plants in shallow trenches-we say shallow, for it is obviously a bad plan to remove all the good soil (as must be done in a deep trench) and put the plants in that which is poor. The plants may be set in a single row 


\section{CELERY-Continued}

in a narrow trench, or the trench may be made into a bed wide enough to hold two, three, or four rows, and in case the plants are in a compact form, to be covered for the winter where they grow. When grown in beds this way, the rows should be one foot apart, and the plants about eight inches apart in the rows. The bed should be made very rich with thoroughly decomposed manure. The plants will need to be earthed up two or three times, and in doing this care should be taken not to let the earth get into the heart of the plant. In field culture the plants are set on the surface in rows four feet apart when the celery is to be earthed up in the field for early use, and two feet apart when the plants are to be taken up and blanched in the cellar for winter use. The plants are set six inches apart in rows. If not grown in beds the best way to store is to dig trenches in a well-drained spot in the open ground, one foot wide and of a depth a few inches less than the height of the celery. The plants are then lifted and set close together until the whole quantity is stored. The edges of the trench should be made sloping from the tops, of the plants. When severe cold weather comes on, cover gradually with leaves, hay or straw and place boards on top. In such a trench the stalks. will blanch perfectly, and may be taken out any time during the winter for use or sale as required.

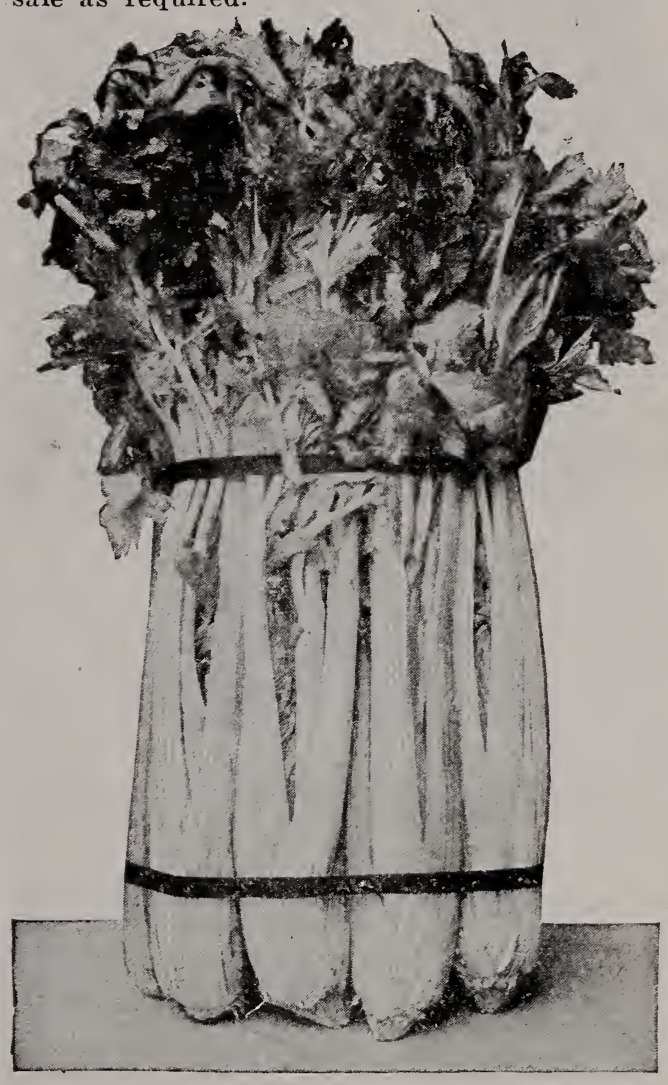

Giant Pascal
IMPROVED WHITE PLCME-Naturally white or light foliage; requires but little banking up to blanch; very early and extensively grown for market. Pkt., 5c; oz., 20c; $1 / 4$ 1b., 70c.

GOLDEN SELF-BLANCHIXG-A grand solid rariety, on the style of the White Plume, except that it is golden yellow where the Plume is white. Pkt., 5c; oz., $30 c ; 1 / 4$ lb., $\$ 1.00$.

GIANT PASCAL-An easily blanched and fine keeping large sort, of excellent flavor: superior for late use. Pkt., 5̃c; oz., 20c; 1/1 lb., 70c.

GIANT WHITE SOLID-Large, round, crisp and solid; the old well-known variety. Pkt., 5c; oz., 20c; 1/4 lb., 70c.

CELERIAC OR LARGE S M O O T H PRAGUE-An improved form of the rooted celery, roots smooth and round. Pkt., 5c; oz., 30c; $1 / 4$ lb., $\$ 1.00$.

CELERY FOR FLATOR-Per lb., 25c; per 5 lbs., $\$ 1.00$.

\section{CORN SALAD, or Fetticus}

CULTURE-Sow during August or early in September, in drills a quarter of an inch deep and six inches apart. If the weather is dry when the seed is sown, tread it in slightly to insure germination. Keep down weeds with hoe. Just before winter cover thinly with straw or leaves.

LARGE SEEDED - The best rariety for family use; makes delicious salad; used during the winter as substitute for Lettuce. Pkt., 5c; oz., 10c; 1/4 lb., 40c.

\section{COLLARDS}

CULTURE-Sow seed as for Cabbage in June, July and August for succession; transplant when one month old in rows a foot apart each way and hoe often. GEORGIA GROWN OR SOUTHERNPkt., 5c; oz., 15c; 1/4 1b., 50c.

\section{CRESS}

CULTURE-Sow thickly in shallow drills every two or three weeks. It is useful not only for salad, but for the breakfast table and for garnishing. Water Cress should be sown in damp soil, or if a stream of water can be utilized, it would be much finer. It will also thrive in damp hot-beds. Rightly managed its culture is very profitable. To obtain early salad, it is a good plan to sow with Water Cress seed a strip four inches wide on the outer margin of a hot-bed, inside the frame (where it is always cool). This will be found a satisfactory method of obtaining it early.

CURLED OR PEPPER GRASS-Pkt., 5c; oz., 10c.

BROAD LEAVED-Pkt., 5̃c; oz., 10c.

BROAD LEAVED WINTER-Pkt., 5c; oz., 10c. $40 \mathrm{c}$. 


\section{CORN, SWEET AND FIELD Pedigreed Seed Corn vs. Elevator Seed Corn}

In Seed Corn, as in everything good, there is much hypocrisy and deceit-in other words, plain lying, so that the farmer hardly knows whom to trust or where to get good seed. Many seedsmen, mushroom fellows, making high claims, hoping to get rich in a rear or two, are sending out only scoop shorel or elevator corn. This has a tendency to bring the whole seed corn business into disrepute. We don't ask you to take our word for what we say of our method of growing, handling and caring for seed corn, but we do ask zou in good faith to come and see us, go through our corn drying cribs, look our corn over, watch us closely butt and tip the ears, see that in many cases we reject one-third to one-half the com, examine the whole process from the field to the bag or crate, and if you are not satisfied that our seed corn is all, even more, than we claim for it, we will pay all your expenses coming and going and at the city. Possibly you cannot come yourself. Have you not a friend vhom you can send-someone living in or near our city Send him; we will stand or fall by is report.

\section{Ear Seed Corn}

For the past two or three seasons there has been quite a large demand made upon us for seed corn in the ear. We have selected from our 6.000-acre plant some very choise stocks of all the varieties we catalogue, and we shall be prepared to fill orders in 70-pound crates. WVe have selected these ears from our stock that show high vitality and pure breeding, and any farmer desiring to buy corn on the ear can get no better stocks from any part of the United States for the territory we cover. It is recommended by some of the expert carn growers that the butt and tip of the corr should be shelled off and rejected. These ears will be found so perfect that there will be but little loss on that account, and while we recogni:e the impossibility to furnish to our trade every ear an iaeal ear, we have undertaken to nut up a stock that, used by the farmer, will bring to us additional trade in the years that are to come. In the olden times it was the custom of the family to card the wool, to spin the yarn, to weave the fabric, to make the garment, all in the same family, and all done by one and tse same person. That time is past, and today is a day of specialists. One man can breed hig, types of corn to better adrantage and at a very great saving of expense for the communit? than each member of the community can do for himself. It shall be our honest endeavor, a: long as we are permitted to continue the seed business here, to make this department of our work a benefit to the agricultural district surrounding us. We realize what it will mean if by bonest endeavor we can help to add ten or twenty per cent to the arerage vield of the corn crop of the Northwest. We urge upon our farmers not to plant too late varieties of corn. rhe market reports for the last four years indicate that the corn in our latitude has failed to make grade, and this is due largely to importing. seed stocks from the South.

\section{Extra Early Varieties}

Market gardeners and private owners will do well to consider that our Northern grown seed will give them earlier corn than will seed of the same varieties grown farther south. Our seed is thoroughly tested before it leaves our hands.

\section{DON'T PLANT SWEET CORN DEEP}

Sweet Corn should not be planted orer one inch deep; most people plant two or three inches deep-most sure to rot. Also do not plant too early. Not as early as field corn.

White Mexican Do you know the marrelous sweetness of the old Black Mexican? You like White Mexican its taste, but dislike its color. Well, we have something finer in every way, superior in sweetness, a pure irory white color, large as the Minnesota, earlier than the

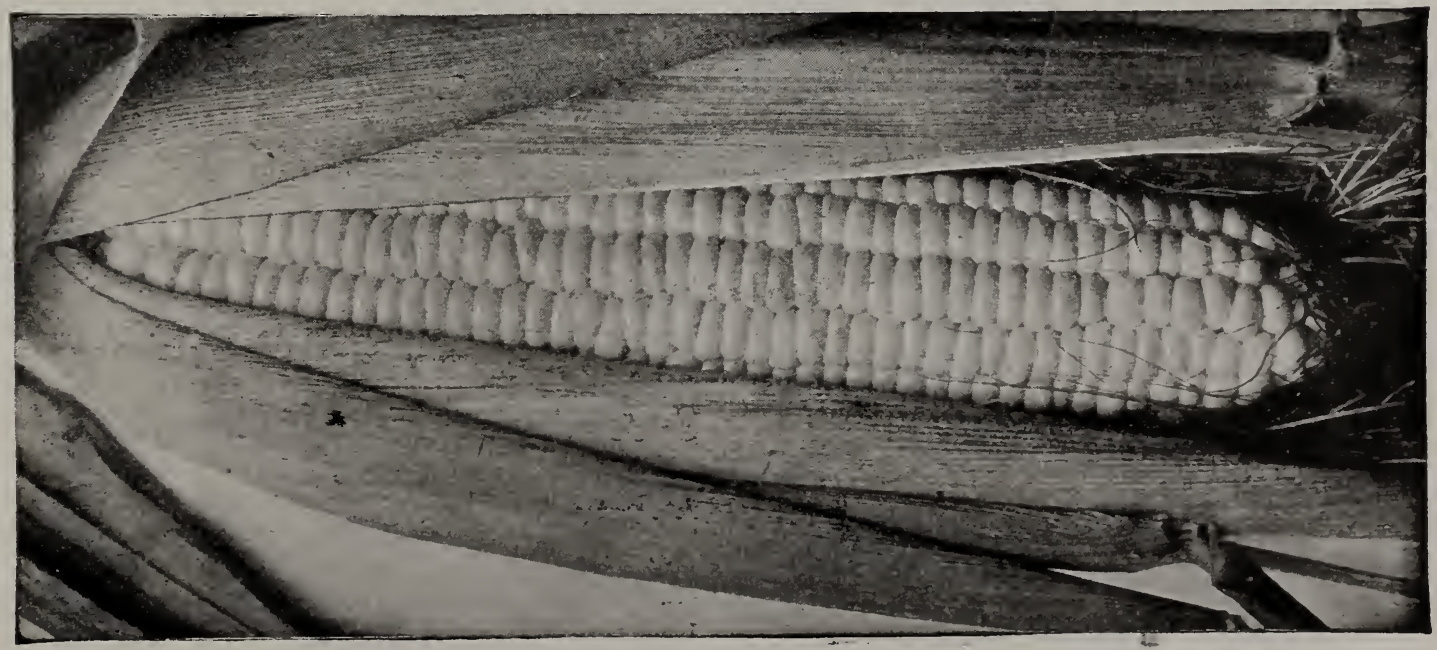




\section{CORN-Continued}

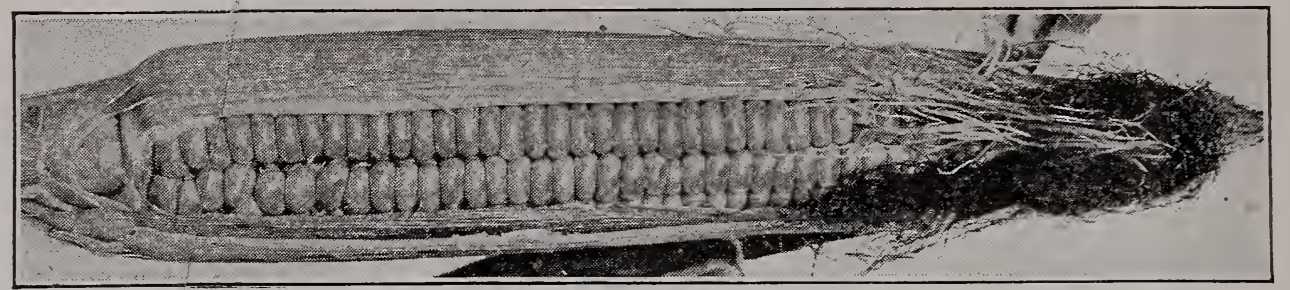

Golden Bantam

Cory. It was ready for table use this year in 55 days. Originated in Fort Dodge, Iowa. Was placed in our hands for trial and development. We know of nothing its equal for the market gardener. If you want the finest market gardener's corn known, plant White Mexican. Pkt., $15 \mathrm{c} ; 1 \mathrm{~b} ., 30 \mathrm{c}$.

"I planced the White Mexican Sweet Corn you sent me. I have been planting sweet corn for 25 to $3 C$ years. This White Mexican is superior to any extra early sweet corn I ever saw. Was ready.co eat 58 days from planting."-H. B. Smith, Odebolt, Iowa.

"I planted your White Mexican this season, at the same time I planted extra early sweet corn from an eastern seed house. I found the White Mexican earlier and superior in every way. It's ths finest early corn I ever had."-Desing Bros., Marshalltown, Iowa.

"Gents: We began seliing your celebrated White Mexican Sweet Corn some three years ago in a small way for a trial. Now our market gardeners want nothing else for their early and extia early crop. It's the earliest of all; fine looking ear and as sweet as Erergreen. Book us for 14 bushels."-Darling \& Beahan, Petoskey, Mich.

\section{Sweet or Sugar Corn \\ From 55 to 65 Days}

GOLDEN BANTAM-Of extreme hardiness; can be planted earlier than any other true sweet corn and will then produce the earliest supply of ears for the table. Extra fine in quality. Pkt., 15c; 1b., 30c.

PREMo-An extremely early variety, usually fit to use in about 50 days from time of planting. It is not only very early, but it is one of the sweetest and best. This variety combines all the good qualities of the later sorts, is much hardier...., and may be planted some days earlier without danger of rotting. It is a vigorous grower; stalks about 5 feet high. Pkt., 15c; 1b., 30c.

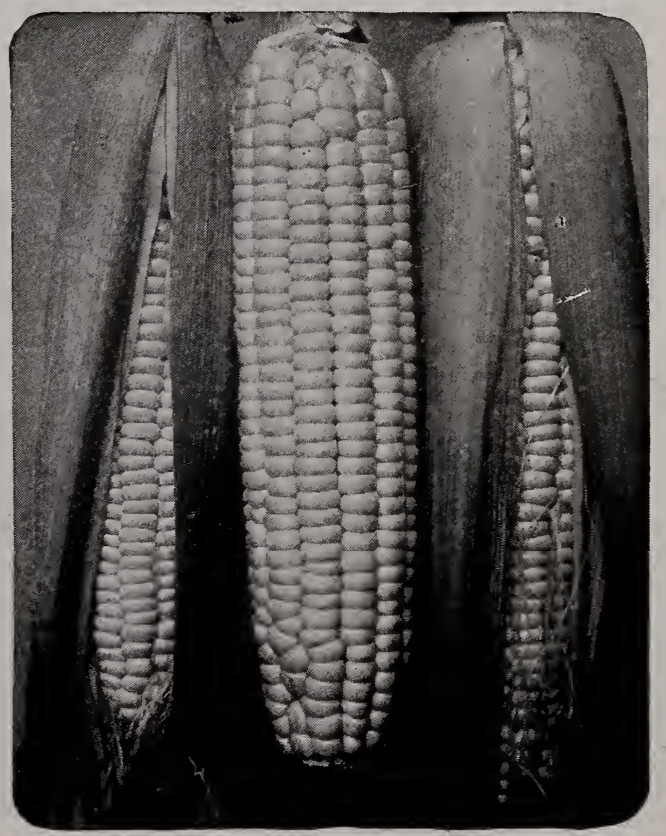

Stowell's Evergreen
PEEP OF DAY-This most valuable sort is of Minnesota origin, and is not only early, but one of the best. The stalks grow from 3 to 4 feet high. Ears average from 5 to 6 inches in length and are of perfect form. Pkt., 15c; 1b., 30c.

EARLY CORY, RED COB-A new early variety, with good sized ears and large grains; excellent for market. Pkt., 15c; lb., 30c.

WHITE COB CORY-Resembles the ordinary Cory in size and earliness, but with white cobs; very much better quality. Pkt., $15 \mathrm{c} ; 1 \mathrm{~b} ., 25 \mathrm{c}$.

MAMMOTH WHITE CORY-Largest extra early corn known; fine quality, 12-rowed compact ears. Pkt., 15c; lb., 30c.

MARBLEHEAD-One of the earliest; dwarf, with short, thick ears; of good quality for an early sort. Pkt., 15c; lb., 30c.

EXTRA EARLY ADAMS-Not a sugar corn, but largely grown for early use. Pkt., 15c; 1b., 20c.

\section{Second Early or Intermediate From 65 to 80 Days}

MINNESOTA-Nearly as early as Marblehead; dwarf growth; standard. Pkt., 15c; 1b., 30c.

PERRY HYBRID-Very early and of large size; most valuable for market. Pkt., 15c; 1b., 30c.

SHAKER EARLY-Very large, white grain and quite early. Pkt., 15c; lb., 30c. 


\section{CORN-Continued}

EARLY CROSBY-Matures after the Minnesota: fair sized ears of good quality. Pkt., 15c; 1b., 20c.

EARLY ADADIS-Not a sugar corn, but grown extensirely all orer the country for market purposes. Pkt., 15c; lb., 20c.

EARLY CHAMPION-A new and rery desirable sort; ears nearly as large as Evergreen; pure white; only a few days later than Minnesota; rery fine for market gardeners. Pkt., 15c; lb., 30c.

EARLY MAMIOTH-Tery large and not late. 1 lb., $30 \mathrm{c}$.

\section{General Crop or Late Varieties}

OLD COLONY-A very good late variety of rery rich, sweet flaror; ears bear 16 to 20 rows of kernels, and are rery heary and solid. Pkt., 15c; 1b., 30c.

STOWEL'S EVERGREEY-Remains a long time, and is highly prized; one of the most popular rarieties. Pkt., 15c; 1b., 25c.

IMPROVED WHITE EVERGREENThe cobs and kernels are at all stages of edibility beautifully white. The getting rid of the amber tint so prominent in a great many strains of sweet corn passing for Stowell's Erergreen is a great gain, as it fits this variety for extensive use in canneries. Pkt., $15 \mathrm{c}$; 1b., 25c.

ZIGZAG EVERGREEN-A cross between Country Gent and Evergreen. It has the

\section{FIELD CORN,}

MINNESOTA KING-Ears 7 to 8 inches, 85 days. A famous half dent, 8-rowed corn; a rery choice rariety for Minnesota and $\mathrm{Da}$ kota.

SQUAW CORN-Ears 10 to 12 inches; 75 days. Has as many colors of kernels as Jacob's coat-white, yellow, red and black; a very fine variety.
EARLY EVERGREEN-By careful selection for a series of rears we have produced an early strain of this corn, earlier by 6 to 8 days. Pkt., 15c; 1b., 25c.

BLACK MEXICAN-Very sweet and of superior flaror; grains black. Pkt., 15c; lb. $30 \mathrm{c}$

HICKOX-Earlier than Stowell: large ear; fine quality; plant with Stowell and it will come 10 days earlier. Pkt., 15c; 1b., 30c.

KENDEL'S EARLY GIANT-Early, yet the ears grow to a good size. It has a white cob and pure white kernels, which are sweet and tender. Pkt., 15c; 1b., 30c.

very high quality of the Country Gent with almost the size of the Erergreen. A little earlier than either parent. Pkt., 15c; 1b., 30c.

NE PLCS ULTRA-Small, but one of the sweetest sorts grown. Pkt:, 15c; 1b., 35c.

LATE MAMMOTH-Rank in growth, large ears, rich and sweet. Pkt., 15c; 1b., $30 \mathrm{c}$

EGYPTIAN-Large and of superior quality ; largely used for canning. Pkt., 15c; lb., 30 c.

CONNTRY GENTLEMAN-Same as Ne Plus Ultra, but with large ears of delicious quality. Pkt., 15c; 1b., 35c.

SWEET CORN FODDER-For soiling and ensilage. .M. $\mathbf{P}$

\section{Early Varieties}

SMUT NOSE-12 to 14 inches long; 75 days. A peculiar yellow flint. One side of the end of the ear has a peculiar red place. Fine variety.

TRIPLE INCOME-Ears 6 to 8 inches: 80 to 85 days. A white capped yellow Dent corn. Positively the very best corn in exist. ence. Will shell 64 to 74 pounds of cob. The corn for Minnesota and Dakota.

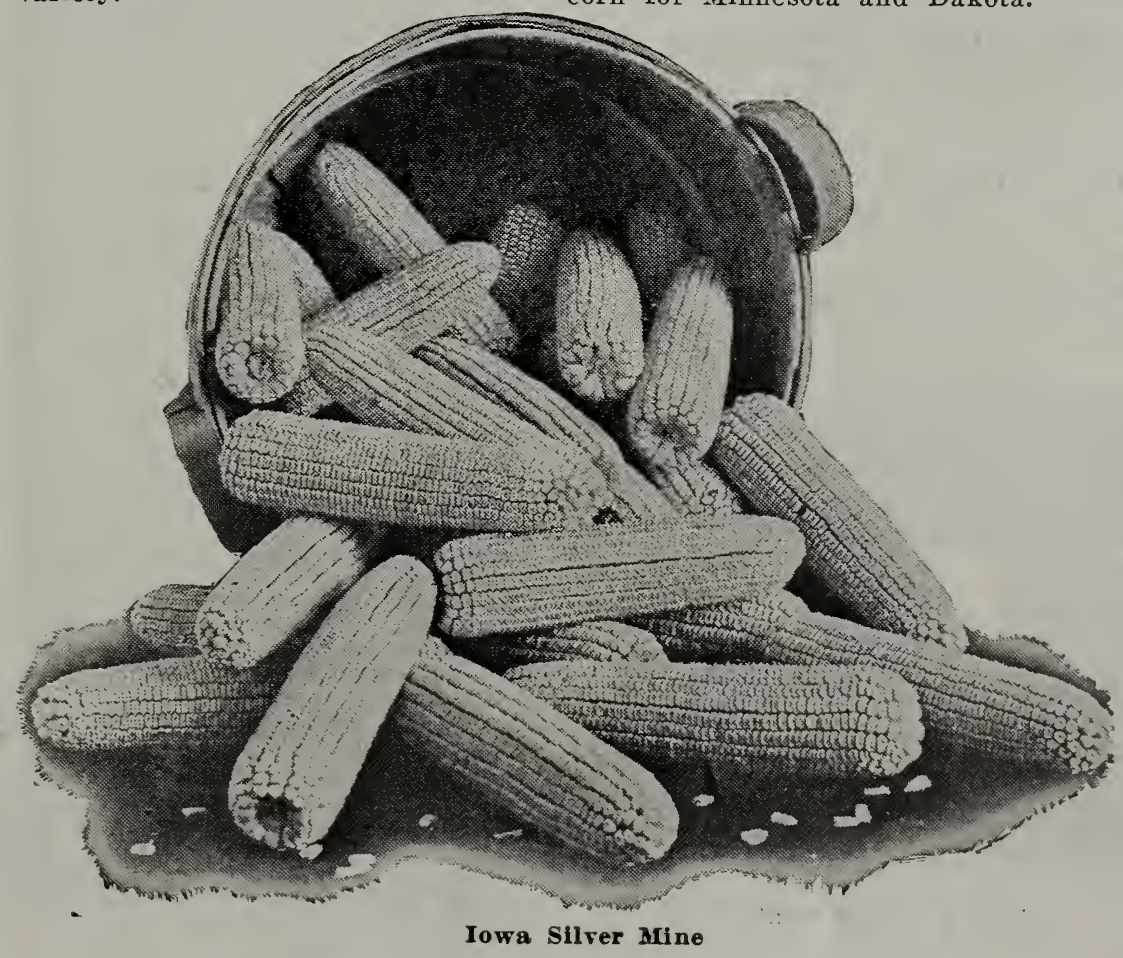




\section{CORN-Continued}

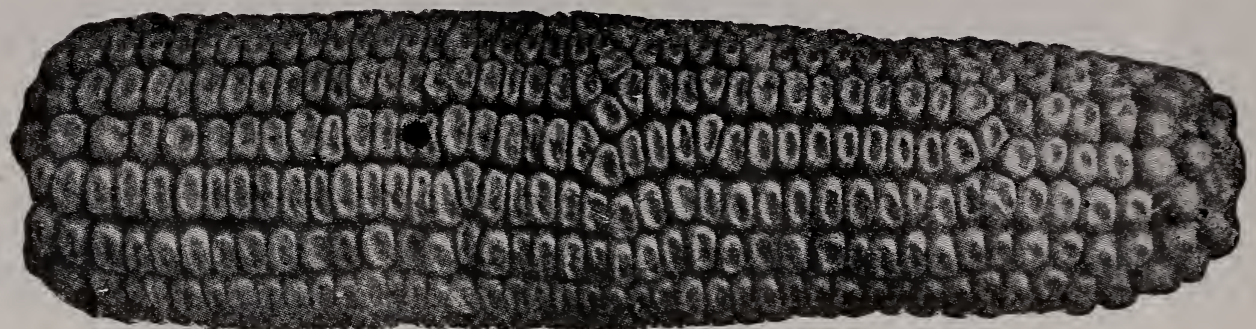

Early Longfellow Dent

IMPROVED YELLOW FLINT-85-day corn: a very good corn for the far North; small cob, good yielder.

WISCONSIN WHITE DENT-Ears 8 to 9 inches; 90 days. Resembles the Silver Mine; beautiful clear dented corn, long kernel, small cob; finest white for north of Sioux City.

WHITE FLINT (OLD HOMINY)-Has large silver white kernels, a very large ear, sinall cob.

WHITE FLINT-Ears 12 to 15 inches: 75 days, A very long-eared flint corn, adapted to the far North, and for early feed.

MERCER (Extra early yellow flint)Prolific, good sized ear and small cob. Has been grown in northern Minnesota and North Dakota for the past 10 years with great success and complete satisfaction.

\section{EARLY MURDOCK-}

PRIDE OF THE NORTH-Ripens in about 85 days: yellow Dent: one of the best corns for the Dakotas and for replanting.

DULY'S HYBRID-Ripens in 90 days (see fuller description on next page).
IMPROVED CALICO-The old-fashioned striped calico corn has alrrays been popular as a feeding corn and we have had so much inquiry for a good strain of it that we grew a field of it this year and will offer it for sale. The ears run 10 to 11 inches long, that is. the best ones: very deep grains and heary. Color a combination of red and yellow in stripes. The grain is very rich and is preferred by stock to most other corn.

EARLY LONGFELLOW DENT-There is no telling when we will have a short season and early killing frost in the fall, and in such a case farmers who have their fields planted with an early maturing variety are truly fortunate. The trouble with most extra early rarieties, however, is that they are too small and "nubby," but this new rariety is of unusual length, 12 to 15 inches. Its peculiar shape, which is different from any other sort, suggests the name. It matures fully as early as Pride of the North, is about the size and rields a far greater crop, which is ripe and hard before there is a thought of frost, thus making a variety that it will pas to "tie to." Grain is not as deep as some of our other varieties, but it is the corn of corns for selling on the market, as a wagon load of it is as pretty as a picture. We recommend it highly to customers in northern Iowa, Minnesota, the Dakotas and our northern states.

\section{Late Varieties}

REID'S YELLOW DENT-Corn light golden in color; ears 9 to 11 inches long; 18 to 20 rows of kernels, each row containing 50 to 60 kernels.

IOWA GOLD MINE-Now a well-known standard corn and still one of the very best; ripens in about 100 days; grain deep rich

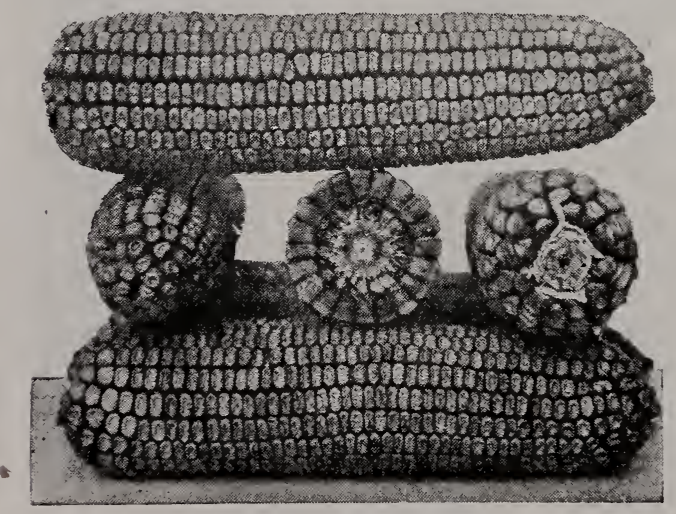

Reid's Yellow Dent yellow dent; very small cob, 70 pounds of ears will shell out.

LEGAL TENDER-This is now one of the most prominent late varieties of yellow dent corn in the country. It is the result of about 10 years' selection by a seed corn specialist in Iowa, and has taken first premiums at many state and county fairs. The corn is productive of uniform pure vellow color; ear very large and long; a deep grain on a small cob. While the stalk does not grow too large. The introducer says: "Our ideal is an ear two thirds as large around as it is long, containing 16 to 20 rows, and small shank. The kernels are deep, the cob is small at butt, and ear holds its bigness toward the point until near tapering off. It matures in about 115 days, but we do not recommend it for the northern portion of this state. Our stock of this is extra select, grown from the originator's stock seed, but improved in earlines: by being grown in a more northern latitude.

IOWA SILVER MINE-One of the rery choicest white corns for the northwest: large beautiful ears; good sheller, about 100 days

LEAMING-Yellow dent, red cob, deer plump grains, rich golden color; vields so tc 100 bushels per acre; about 100 days.

EARLY ROSE-Fine vielder; beautifu yellow dent. 


\section{The Best Variety of Pop Corn}

CHAMPION WHITE PEARL-A rery large white corn, well known in the South.

ROSE-A very productive variety. Ears short, kernels long and pointed. A splendid popping sort; the most salable among the retail dealers. Market Price.

WHITE RICE-Smooth, small grain; ears 4 or 5 inches long, seven-eighths to one and one-eighths inches in diameter. Market Price.

GOLDEN QUEEN-Ears of large size, and the kernels pop to over an inch in diam. eter. One of the best and most prolific vari. eties grown. Market Price.

\section{Duly's Hybrid}

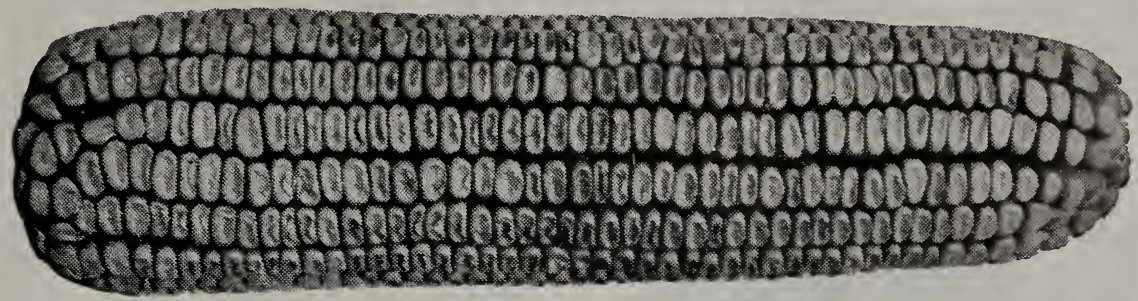

Duly's Hybrid

We wish we could thoroughly impress upon the farmers of Iowa, Nebraska, southern South Dakota and Minnesota the great ralue and safety in placing our Duly's Hybrid. We will place it alongside of any ccrn of any name by any seedsman and show conclusively that there is no corn for this latitude equal to it in merits. Let us give you a little of its history: Some ten years ago we found this corn in the hands of a Mr. Duly, of Dakota City, Nebraska, a thorough, practical, hard-headed farmer, who made great claims for it. We purchased some of the corn for seed and have given it a thorough test in these years and have had reports from thousands of farmers as to its value. It has even proven a greater corn than we had anticipated. When we first found the corn it was rather too light a yellow and the ears too slender and long and kernels too short, but in these ten years, by careful breeding, we have brought it to a much higher state of perfection. The color is much deeper, the ears not quite so long and of greater circumference, and the kernels are deeper. In all of our experience we have never had a corn with such potency. In all kinds of weather, soil and under all conditions, it comes up smiling, with strong, vigorous stalks, large, beautiful ears and plenty of them. At first it is apt to be condemned, but we have yet to find the first planter who, after having planted and grown it, condemns it, but all of one accord sing its praises. Duly's Hybrid will stand more rough treatment than any corn we ever saw-cold, wet, drought, light frosts, etc. It will give a good stand in cold, wet weather when other corns will not. It belongs to the 90-day class of corn and is as heary a yielder as the best, running 70 to 80 bushels to the acre.

Corn 9 to 11 inches

100-Day Corn

\section{FARMERS, DAIRYMEN, STOCKRAISERS Try the Evergreen Sweet Fodder Corn}

The necessity for green fodder is becoming more apparent each year to all dairymen and stock raisers, and the demand for it is increasing in proportion as the ability of our overtaxed lands to supply sufficient pasturage grows less. The best thing for the purpose is our

\section{Evergreen Sweet Fodder Corn}

This variety is generally acknowledged by our best farmers. dairymen and stock growers as being better and far superior to what is known as either of the brands of ensilage corn, Red Cob Ensilage. or Southern White Ensilage. from the fact that it grows to an immense size, making a large, juicy stalk, that is so rery sweet and nutritious that cattle will eat every part of the stalk and leares with a relish, clean to the butt.

Erergreen Sweet Fodder Corn also yields an enormous quantity of leares, and the stalks are rich in saccharine matter-more so than any other variety we are acquainted with. 


\section{CUCUMBER}

ARLINGTON WHITE SPINE-A selection from the White Spine, being more pointed at each end; the young fruits are usually crisp and tender and are of very dark green color, so that the variety is considered by some to be the best for small pickles. Pkt., 5c; oz., 10c $1 / 4$ lb., 35c.

NEW CUMBERLAND-A variety of the hardy White spine type, the pickles being thickly set with fine spines. During the whole period of growth, from the time they first set until full grown, the form is exceptionally straight and symmetrical, making them as choice for a slicing variety as for pickles. Pkt., 5c; oz., 10c; 1/4 lb., 35c.

COOL AND CRISP-Straight, long, slim, dark green, fine for pickling. Pkt., 5c; oz., 15c; $1 / 4$ lb., $40 c$.

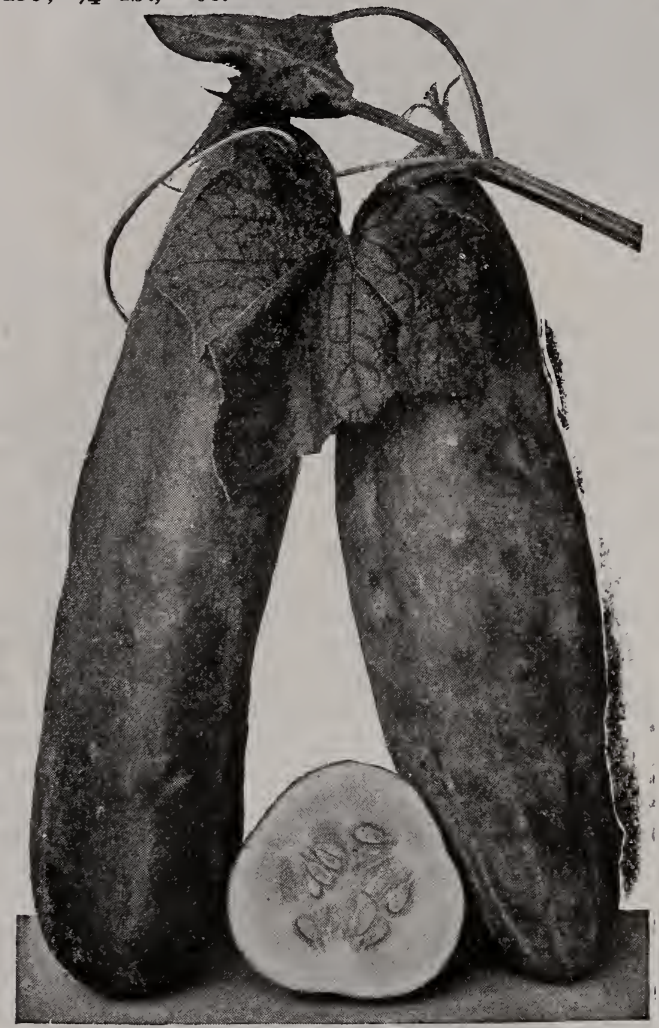

Long Green Cucumber

THE DAVIS PERFECT CUCUMBERAn excellent cucumber for both outdoor use and forcing. It is a carefully selected strain of the extra long White Spine type made by a veteran outdoor and greenhouse grower of cucumbers. Its valuable points are length, slimness and its dark green color. It is a rery vigorous sort and resists blight longer than most sorts. Pkt., 5c; oz., 15c; 1/4 lb., 45c.

BOSTON PICKLING-A favorite eastern sort of fine quality. Pkt., 5c; oz., 10c; 1/4 lb., 35c.

CHICAGO PICKLING-Very popular in Chicago market. Color deep green, medium size, prominent spines. Pkt., 5c; oz., 10c; $1 / 4$ lb., 35c.

EARLY RUSSIAN-Very early, short, is a valuable variety for small pickles, for which it is often in demand. Pkt., 5c; oz., 10c; $1 / 4$ 1b., 35c.
EARLY SHORT GREEN (or Early Frame)-Good for pickling; productive. Pkt., 5c; oz., 10c; 1/4 1b., 35c.

EARLY GREEN CLUSTER-Fruit small and in clusters; very prolific. Pkt., 5c; oz., $10 \mathrm{c} ; 1 / 4$ lb., 35c.

EARLY WHITE SPINE-Early, and good for pickling or table use. Pkt., 5c; oz., 10c; $1 / 4$ lb., 35c.

EVERGREEN-Very early and prolific: retains its fine deep green color in all stages of growth. Pkt., 5c; oz., 10c; 1/4 1b., 40c.

GREEN PROLIFIC PICKLING-One of the best for pickling, dark green, very productive and of uniform small size. $1 / 4 \mathbf{l b}$., 25c.

JAPAN CLIMBING-Can be grown on trellis. Pkt., 5c; oz., 15c; 1/4 lb., 40c.

JERSEY PICKLING-Medium length, skin thin, pure white. Pkt., 5c; oz., 10c; 1/4 lb., 35c.

IMPROVED WHITE SPINE-Well fla rored and of medium size. Pkt., 5c; oz., 10c ; $1 / 4$ lb., 35c.

LONG GREEN-Long and crisp, a popular and reliable variety for pickles. Pkt., óc; oz., 10c; $1 / 4$ lb., 35c.

LONG GREEN TUR KEY-Fruit very long and rather slim. Pkt., 5c; oz., 10c; 1/4 lb., $40 \mathrm{c}$.

NICHOL'S MEDIUM GREEN-Most symmetrical and a very fine table sort. Pkt., 5c; oz., 10c; $1 / 4$ lb., $40 \mathrm{c}$

SMALL GHERKIN-Very small burr, used for pickles. Pkt., 5c; oz., 10c; 1/4 lb., toc.

SERPENT OR SNAKE-Cucumbers grow curled up like snakes, 4 to 5 feet long; quality fair. Pkt., 5c; oz., 15e; 1/4 lb., 45e.

\section{ENDIVE}

CULTLRE-Sow in June, July and August, cover lightly; when up thin out to eight inches apart and water well afterward, if dry. When the leaves are six to eight inches long, blanch by gathering in the hand and tying together near the top with yarn or bast. This must be done when quite dry or they will rot. At the approach of winter take up carefully with a ball of earth to each plant, and place close together in frame or cellar for use. They must be kept dry and have plenty of air, or they will rot.

GREEN CURLED WINTER-Standard sort for fall and winter crop. Pkt., כe; oz., 15c; $1 / 4$ lb. $45 \mathrm{c}$.

BROAD LEAVED-A sweet variety, fall and winter. Pkt., 5c; oz., 15̃c; $1 / 4$ lb., 45 c.

\section{EGG PLANT}

CULTURE-Sow in hotbeds very early in spring and transplant when two inches high into a second bed or into small pots. If that is not done, thin to four inches apart. Do not plant out until the weather becomes perfectly settled and warm. Cool nights or wet weather will check them.

EARLY LONG PURPLE-Of distinct shade and fine quality. Pkt., 5c; oz., 40c; 1/4 lb., $\$ 1.60$.

ROUND PURPLE-Medium, pear shaped, pale purple, good. Pkt., 5c; oz., 40c; 1/4 lb., $\$ 1.60$.

IMPROVED NEW YORK PURPLE-The best large oval, deep purple, grown more extensively than any other sort. Pkt., 5c; oz., 60c; $1 / 4$ lb., $\$ 2.00$.

BLACK BEAUTY-Fruit broad and thick, rich deep black, spineless, very early. Pkt., 5c ; oz., 50c; 1/4 1b., \$1.75.

FLORIDA HIGH BUSH-Bush grows high and stiff, fruit about like N. Y. Purple, fine shipper, one of the very best egg plants. Pkt., 5c; oz., 60c; $1 / 4$ lb., $\$ 2.00$. 


\section{USEFÚL GOURDS}

NEST-EGG-Resemble in color, form and size the eggs of heris; do not crack, and are uninjured by cold or wet. They make the very best nest eggs. Do not plant in very rich soil, or the fruits will grow too large. Pkt., 5c; oz., 15c; 1/4 1b., 50c.

DISHCLOTH OR LUFFA-A natural dishcloth, and a most admirable one, is furnished by the peculiar lining of this fruit, which is sponge-like and durable. Pkt., 5c; oz., 15c; 1/4 1b., 50c.

\section{KALE, OR BORECOLE}

CULTURE-Cultivated and grown exactly like cabbage. Sow early in the spring in a hotbed and when from one to two inches high transplant into a bed or border that has been highly manured and deeply dug. The plants should stand two feet apart, in rows three feet apart. The soil should be kept mellow and free from weeds. Cover with litter or leares during the winter. Plants started grown this way should be fit to blanch the following spring. The seed may also be sown early in the open border and transplanted in rows (as directed above) as soon as out of the seed leaf; but ther will need to be a year older than the hotbed plants before being fit to blanch.

EXTRA CURLED DWARF GERMAN GREENS-Very dwarf and spreading; best strain. Pkt., 5̃c; oz., 15c; 1/4 1b., 50c.

CURLED TALL GREEN SCOTCH-A taller growth of the above; late rariety. Pkt., 5e; oz., 15c; 1/4 lb., 50c.

SIBERIAN-A fine dwarf variety. Pkt., 5c; oz., 10c; $1 / 4$ 1b., 40c.

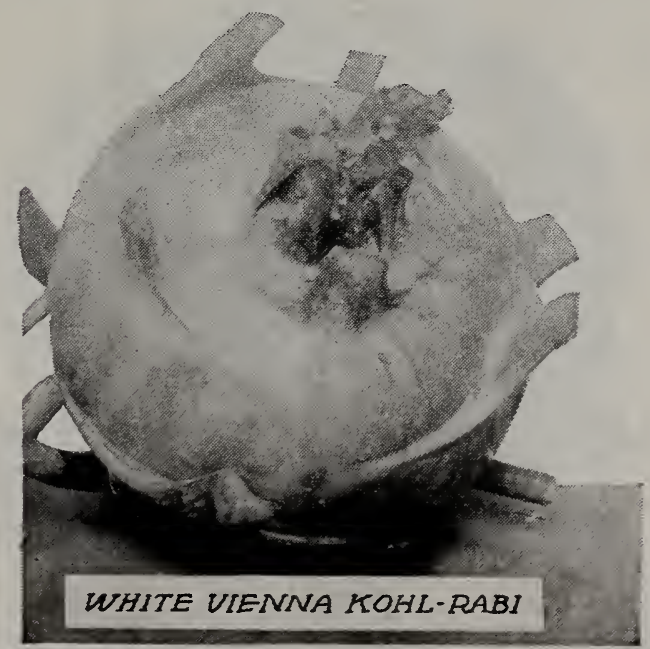

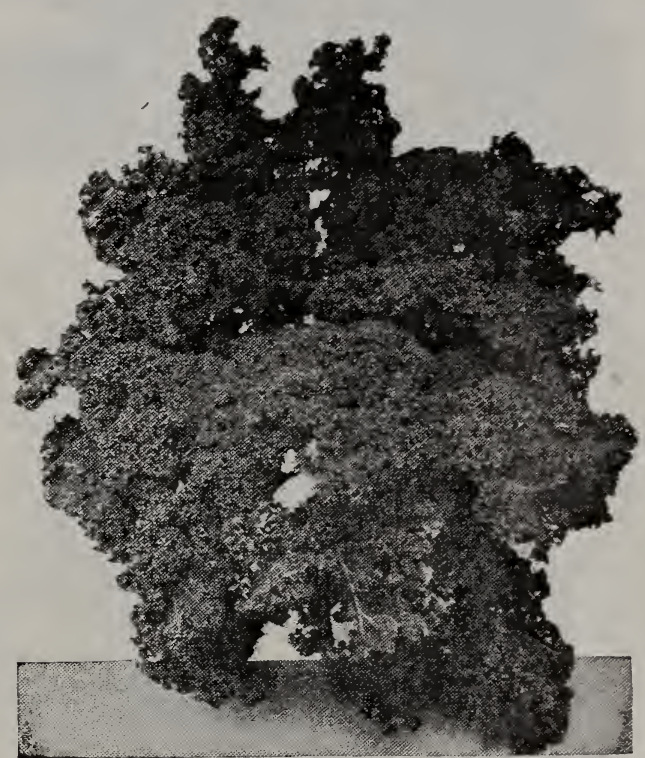

Kale, Moss Curled

\section{KOHLRABI}

CULTURE-This is an excellent regetable and should be grown in every garden. Sow in the spring, in rows eighteen inches apart, afterwards thinning the plants to eight or ten inches. If the weather is suitable, the thinnings may be planted, but it is considered difficult to transplant. Feep the weeds down and when the thickened stem above ground is two or three inches through, they are fit to eat, and should be used at once, being tough when old. They are cooked the same as turnips, and when well grown and used at the proper stage, are tender and palatable.

EARLY WHTE VIENXA-Handsome and delicate, white ball. Pkt., 5c; oz., 20c; $1 / 4$ lb., 60c.

EARLY PURPLE VIENNA-Very good sort. Pkt., 5c; oz., 20c; $1 / 4$ 1b., 60c.

\section{LEEK}

BEST LARGE FLAG WINTER-Hardy and productive. Pkt., 5c; oz., 25c; 1/4 lb., 90c.

LARGE CARENTAN-A superior variety with distinct and dark colored leaves; stout in habit and hardy. Pkt., 5c; oz., 25c; 1/4 lb., 90c.

MUSSELBURG-Large standard sort; remains long in good condition. Pkt., 5c; oz., $25 \mathrm{c} ; 1 / 4$ 1b., 90c. 


\section{LETTUCE}

Ready for Use in 40 to 60 Days

CALIFORNIA CREAM BUTTER-Round, solid heads, medium green, good size, compact, rich buttery taste. Pkt., 5c; oz., 10c; $1 / 4$ lb., 35c.

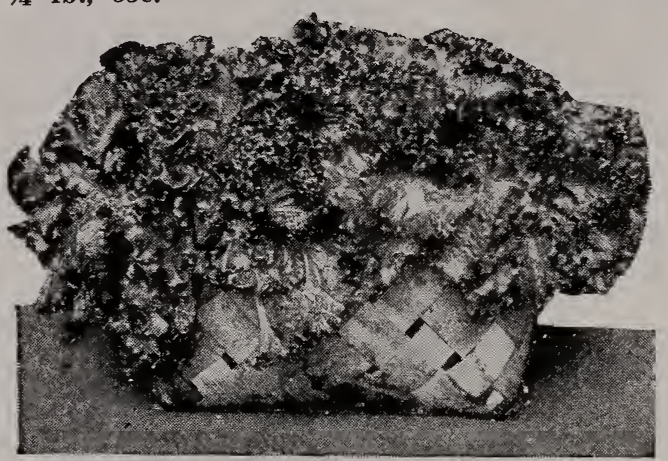

Grand Rapids Lettuce for forcing on open ground; large, solid head; leaves beautifully marked and blistered; very crisp. Pkt., 5c; oz., 10c; 1/4 1b., 35c. early sort; very tender. Pkt., 5c; oz., 10c; $1 / 4$ Ib., 30c.

\section{MUSK}

BURRELL'S GEM-New Salmon-Fleshed Musk Melon-Grown in a comparatively cool location or at a considerable elevation, the Burrell Gem comes close to perfection, having fruits of good size, handsome appearance, and of fine flavor, but when grown in light, warm soils the melons come with softer flesh and are liable to split or crack open at the blossom end. The melons are six to seven inches long by four and a half to five inches in diameter, rather sharply sloping at the ends. They are quite well ribbed and covered with a fine grayish netting. The skin is a rich dark green, contrasting finely with the deep orange-salmon colored flesh, sweet and tender. The flesh is thick and firm, ripening close to the skin, leaving only a thin rind.

PRICE OF BURRELL'S GEM-Pkt., 5c oz., 10c; $1 / 4$ lb., 35c.

BAY VIEW-Very prolific and of great size; oblong; green flesh, late. Pkt., 5c; oz $10 \mathrm{c} ; 1 / 4$ lb., $35 \mathrm{c}$.

BANANA-Cucumber shaped, highly perfumed, of indifferent quality; late. Pkt., 5c; oz., 10c; $1 / 4$ 1b., 35c.
DENVER MARKET-An early variety

EARLY CURLED SIMPSON-A leading

BLACK SEEDED SIMPSON-A superior variety; large and of light color. Pkt., 5c; oz., 10c; 1/4 lb., 30c.

EARLY PRIZE HEAD-Bright green, tinged with brownish red, tender, crisp. Pkt., 5c; oz., 10c; $1 / 4$ lb., 35c.

BIG BostoN-The best large heading early variety. Most popular variety for the southern gardener who ships north. Also very valuable as first early in the North. Plants are large, vigorous; leaves bright, light green, very tender. Our strain is unsurpassed. Many gardeners in the South will plant only Vaughan's Big Boston. Pkt., 5c; oz., 10c; $1 / 4$ lb., 30c.

EARLY CURLED SILESIA-An early, erect growing, clustering variety which may be sown very thick and cut while the plants are very young, at which time they. are exceedingly tender, sweet and well flavored; color light green. Pkt., 5c; oz., 10c; 1/4 lb., 30c.

GRAND RAPIDS FORCING-Large, tender heads, one of the best for early forcing. Pkt., 5c; oz., 10c; 1/4 lb., 35c.

ICEBERG-Fine compact heads which resist summer heat admirably; is very popular; leaves curled and light green; crisp, tender. Pkt., 5c; oz., 10c; 1/4 Ib., 35̃c.

IMPROVED HANSON-Tery large and solid, sweet, crisp and tender. Pkt., 5c; oz., 10c; $1 / 4$ lb., 35c.

PARIS WHITE COS-Fine if sown very early; requires tying up to blanch.

\section{MELON}

EMERALD GEM-Small, extra early: smooth ribbed, dark green skin and orange flesh; quality first rate, very sweet. Pkt., óc; oz., 10c; $1 / 4$ lb., 35e.

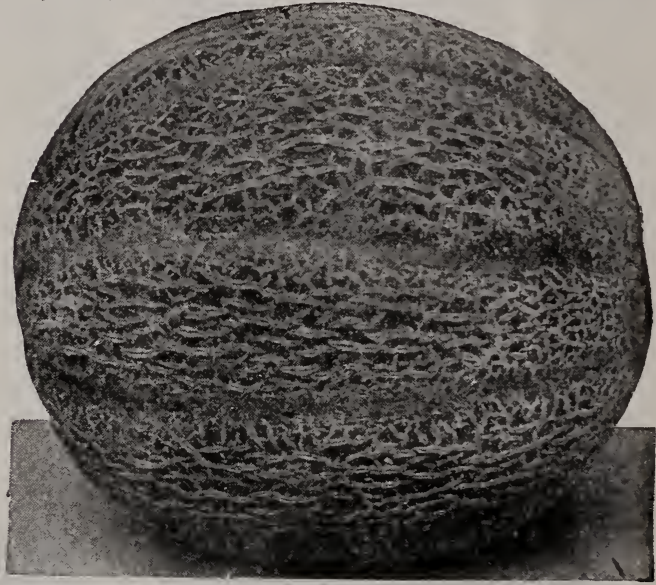

Emerald Gem

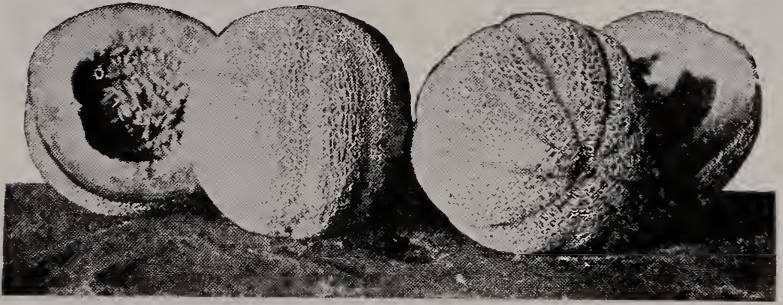

GOLDEN NETTED GEM-Very early ; is small and of fine flavor green flesh. Pkt., 5c; oz., 10c; 1/4 lb., 35̌c.

JENNY LIND-Small, but rery early and of good quality : green flesh. Pkt., c; oz., 10c; 1/4 Ib., 35c.

LONG YELLOW CANTALOUP -Yellow flesh, well adapted for the North; late. Pkt., 5c; oz., 10c; 1/4 lb., 3ร̃e. 


\section{MUSK MELON-Continued}

LATE HACKENSACK-Large, round, and of good quality; a popular rariety. Pkt., 5c; oz., 10c; $1 / 4$ lb., 35c.

NETTED BEAUTY-Extra early; densely netted; flesh pale green. Pkt., כ̃c; oz., 10c; $1 / 4$ 1b., 35c.

OSAGE-Cocoanut shaped, yellow flesh, light green, netted skin; good quality, intermediate. Pkt., 5c; oz., 10c; 1/4 lb., 35c.

HONEY DEW-Round, smooth skinned, flesh light emerald green. Very sweet sugary flavor. Good keeper. Oz., 10c; $1 / 41 b ., 40 \mathrm{c}$.

ROCKY FORD-This is the most popuiar of the basket melons; oval, light ribbed, densely corered with coarse green netting. flesh thick, green and sweet, highly flavored. Pkt., 5c; oz., 10c; $1 / 4$ lb., 35c.

TIP TOP-Melons are round in form, well ribbed; light green skin; flesh is thick. bright salmon in color, of luscious melting character; firm for shipping purposes. Pkt., 5c; oz., 10c; $1 / 4$ lb., 35c.

EXTRA EARLY HACKENSACK-Ripens ten days earlier than the Hackensack. Pkt., 5c; oz., 10c; 1/4 1b., 35c.

GREEN NUTMEG-Named from its shape, green flesh, good for main crop. Pkt., 5c; oz., 10c; $1 / 4$ lb., 35c.

GREEN MONTREAL-Large, round, netted, flesh thick and light green; late. Pkt., 5c; oz., 10c; $1 / 4$ lb., 35c.

PAUL ROSE OR TETOFSY-Unsurpassed in quality, unexcelled for shipping, flesh firm, rich orange color, corered with dense netting not ribbed. Pkt., 5c; oz., 10c; 1/4 lb. $35 c$.

PRINCESS-Salmon fleshed, rery distinct, nearly round, dark green, netted, sweet and luscious. Pkt., 5c; oz., 10c; 1/4 lb., 35c.

SHCMWAX's GIANT-Very large, cream yellow, very distinct, salmon colored flesh, sweet and luscious. Pkt., 5c; oz., 10c; $1 / 4$ lb. 35e.

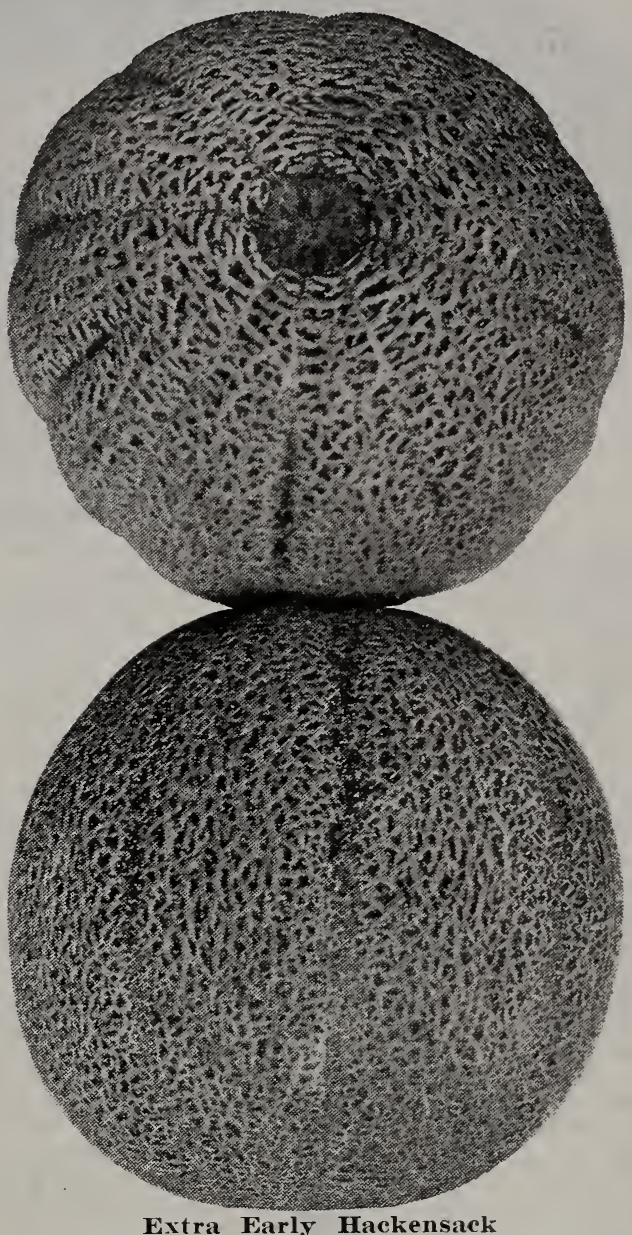

\section{MUSTARD}

CLLTCRE-Sow thickly during earls spring in shallow drills and press the earth down. For fall salad, sow in September or in frames or boxes during the winter.

BLACK-These seeds form the mustard of commerce. Pkt., 5c; oz., 10c; 1/4 1b., 30c.

\section{WATER MELON}

Ready for Use in 60 to 90 Days

CITRON-Round and handsome, for preserring; late. Pkt., 5c; oz., 10c; 1/4 1b., 30c.

COLE' EARLX-Very early, very sweet; fine home melon. Pkt., 5c; oz., 10c; 1/4 lb., 30c.

CUBAN QUEEN-Solid and hears, skin marked regularly; excellent quality; early. Pkt., 5c; oz., 10c; 1/4 lb., 30c.

DARK ICING-Solid, with dark thin green skin; of superior quality; white seed; early. Pkt., 5c; oz., 10c; $1 / 4$ lb., 30c.

DIXIE-A new melon of excellent quality; rery large and solid, flesh red; intermediate. Pkt., 5c; oz., 10c; $1 / 4$ lb., 30c.

FLORIDA FAVORITE - A superior strain; improvement on Rattlesnake; intermediate. Pkt., 5c; oz., 10c; 1/4 1b., 30c.
WHITE LONDON-Leares used for salad while young: grows very rapidly. Pkt., 5e; oz., 10c; $1 / 4$ ib., 30c.

GIANT SOUTHERN CCRLED-Very large leaves. Pkt., 5c; oz., 10c; 1/4 1b., 30c. CHINESE CCRLED-Fine leaf, excellent for salad. Pkt., 5c; oz., 10c; 1/4 1b., 30c.

FORDHOOK EARLY-An extra early, of extra fine flaror, and large size; color a uniform green: arerage weight from 30 to $t 0$ pounds. Pkt., 5e; oz., 10c; 1/4 lb., 30c.

GEORGIA RATTLES. FII -Oblons dark and striped; bright red flesh; late. Pkt., 5c; oz., 10c; 1/4 lb., 30c.

GRAY IONARCH OR LONG LIGHT ICING-Largest melon grown; crimson flesh; fine; late. Pkt., 5c; oz., 10c; $1 / 4$ 1b., 30c.

HALBERT HONEY-Brought out by Burpee a couple of years ago as the sweetest of all melons, and I am inclined to beliere that he is right about it. They are much like Kleckley, but longer in shape; dark green, very sweet and very tender. Break easily in handling. Large size and fine for home use or nearby market. Pkt., 5c; oz., 10c; 1/4 lb., 30c. 


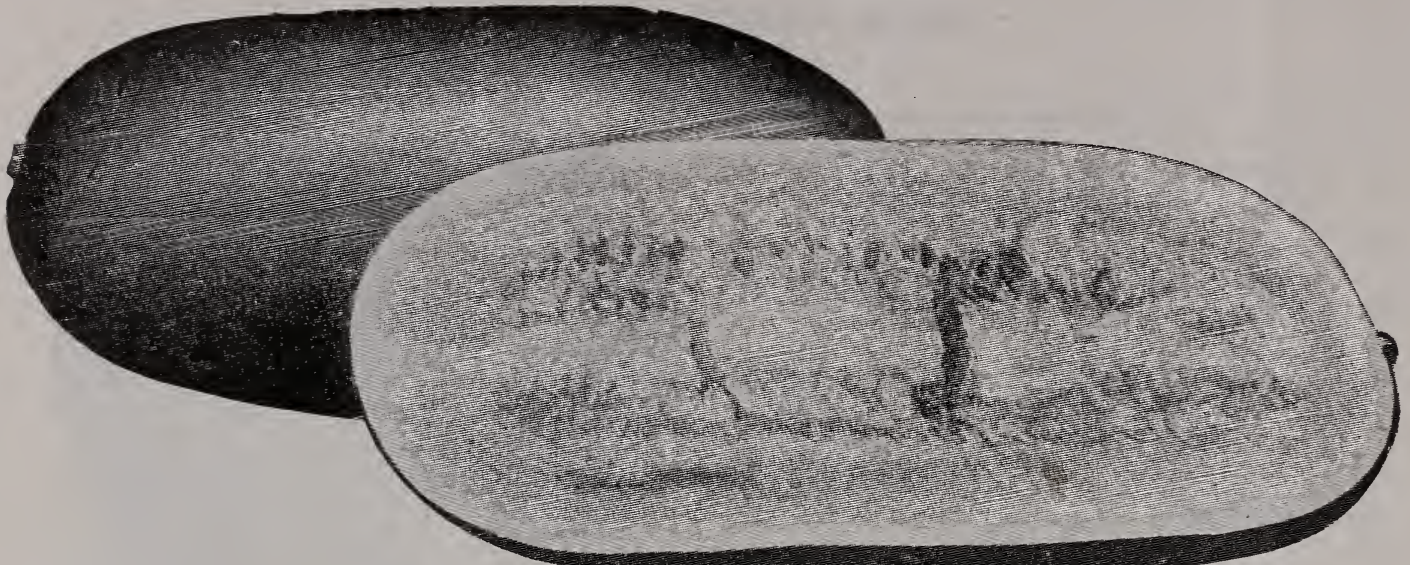

GOLDEN HONEY-Yellow meated, fine flavor. Pkt., 5c; oz., 10c; 1/4 lb., 30c.

ICEBER G (BLUE GEII)-Large, thick, oval form, rich dark green, fine shipper. Pkt., oc; oz., 10c; $1 / 4$ lb., 30c.

HUNGARIAN HONEY-A very early sort from Hungary; fine for northern latitudes; perfectly round, flesh brilliant red, seeds very small. Pkt., 5c; oz., 10c; $1 / 4$ 1b., 30c.

KENTUCKY WONDER-Oblong, dark green skin, scarlet flesh. Pkt., 5c; oz., 10c; $1 / 4$ lb., 30c.

KLECKLEY'S SWEET OR MONTE CRISTO-Oblong, rich dark green, flesh bright scarlet; very sweet. Pkt., 5c; oz., 10c: $1 / 4$ lb., 30c.

KOLB GEM-Large, bright red flesh, of fine quality and a good shipper, intermediate. Pkt., õc; oz., 10c; 1/4 lb., 30c.

ANGEL KISS-Long light grey melon; good keeper; white seed; very sweet. Oz., 10c: $1 / 4$ lb., 30c.

LIGHT ICING-Round, pink flesh, of fine quality. Pkt., 5c; oz., 10c; 1/4 lb., 30c.

MOUNTAIN SWEET-Large oval vari- ety, green rind, flesh scarlet, sweet and delicious; fine for home garden. Pkt., 5c; oz., 10c; $1 / 4$ 1b., 30c.

MeIVER'S SUGAR-Resembles the Rattlesnake, but is very much superior; fine shipper. Pkt., 5c; oz., 10c; 1/4 lb., 30c.

PEERLESS OR ICE CREAM-Very early ; red flesh, good home melon. Pkt., 5̌; oz. $10 \mathrm{c} ; 1 / 4 \mathrm{lb}$., 30c.

PHINNEY's EARLY-Early and of fine quality; red flesh, fine for the North. Pkt., 5c; oz., 10c; $1 / 4$ 1b., 30c.

SWEET MOUNTAIN-An old and reliable sort; flesh red, late. Pkt., 5c; oz., 10c; 1/4 lb., 30c.

SEMINOLE-Very large; quality first rate; intermediate. Pkt., 5c; oz., 10c; 1/4 lb., 30c.

SWEETHEART-One of the best early shipping melons; fruit large, oral, mottled, light green, flesh bright red, firm, melting and sweet. Pkt., 5c; oz., 10c; 1/4 1b., 30c.

ALABAMA SWEETS-Long, dark green, fine flavor, fine shipper. Pkt., 5c; oz., 10c: $1 / 4$ Ib., 30c.

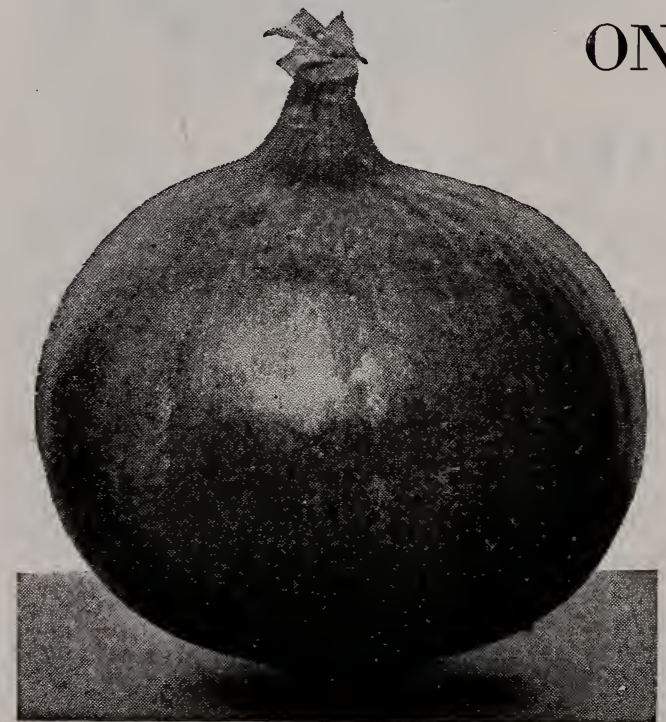

Red Wethersfield

AUSTRALIAN BROWN, the Great Set Onion-A grand new onion from Australia. This is a truly remarkable variety, remarkable in three ways: 1st, they ripen extremely early; 2d, they keep almost indefinitely, much longer than will any other onion; $3 \mathrm{~d}$, they never make any thick necks or scallions. Oz., 15c; 1b., \$2.00.
LARGE RED WETHERSFIELD-Half early and a good keeper; standard sort. Pkt., 5c; oz., 20c; $1 / 4$ lb., 70c.

GLOBE WETHERSFIELD-Cross between Red Wethersfield and Large Red Globe; beautiful onion, fine keeper, fine for the market gardener. Pkt., 5c; oz., 20c.

LARGE RED GLOBE-Southport strain, one of the best reds, good keeper Pkt, oz., 30c; 1/4 1b., 90c.

WHITE BARLETTA-Small white sort; earliest of all, fine for pickling. Pkt., 5c; oz., 30c.

NEW QUEEN-Very early small white sort, the best for pickling. Pkt., 5c; oz., 30c. LARGE WHITE PORTUGAL-Standard sort, flat. Pkt., 5c; oz., 25c.

LARGE WHITE GLOBE-Large Southport strain. Pkt., 5c; oz., 25c.

EARLY RED FLAT-Color of Wethersfield, early. Pkt., 5c; oz., 20c.

YELLOW DANVERS (Flat)-A standard sort, rather oval, early, good keeper.

YELLOW GLOBE, DANVERS-Of more globular shape; keeps well. Pkt., 5c; oz., 20c.

LARGE YELLOW GLOBE-Southport strain, large, firm, mild, good keeper. Pkt. 5c; oz., 20c.

YELLOW STRASBURG-Fine keeper, the great set onion. Pkt., 5c; oz., 20c.

MAUL'S PRIZETAKER-Very large beautiful onion, white flesh, skin straw color sweet, mild, tender; keeps medium. Pkt., 5c; oz., 20c. 


\section{OKRA, OR GUMBO}

CULTCRE-Sow as soon as all danger of frost is past, in drills about an inch deep. The tall kinds require fences or poles on which to climb. The seeds are used for flavoring pickles or as a substitute for capers. $40 \mathrm{c}$.

TALC MIXED-Pkt., 5c; oz., 15c; 1/4 lb.,

DWARF MIXED-Pkt., 5c; oz., 15c; 1/4 1b., 50c.

\section{NASTURTIUMS}

CULTURE-Sow late in the spring, after the ground has become warm, in drills three feet apart, where the plants are to remain. Thin out from nine to twelve inches. They should be well manured. They may also be raised in pots or a hotbed and transplanted. DWARF-Pkt., 5e; oz., 5c; 1/4 1b., $15 c$.

LONG GREEN-Pkt., 5c; oz., 5c; $1 / 41 b$. $15 \mathrm{c}$.

EARLY DWARF-Pkt., 5c; oz., 5c; 1/4 1b., $15 \mathrm{c}$

WHITE VELVET-Long pods; fine flavor; very tender. Pkt., 5c; oz., 5c; 1/4 lb., 15c.

\section{PEAS}

Ready for the Table in 50 to 70 Days.

CCLTURE-A week may be gained in earliness by sowing a quantity in moist sand, placed in a box in the cellar, planting outside when well sprouted. Light, dry soil, not over rich, suits the pea. Sow as early as the ground can be worked, and again erery ten days, for succession, up to the first of Jine, after which there is danger from mildew. Sow in single or double rows, from four to six feet apart, according to the different heights, about an inch apart in rows (except such sorts as we note to sow thin) and four inches deep. Hoe often and keep the ground clean and fine. The tall sorts can be made to bear more freely by pinching-in. The dwarf varieties may be grown in beds like Bush Beans, with rows about the . The holes which are sometimes found in peas are caused by the Pea This insect is native of this country, but, as usual with such pests, has spread rapid and is now found nearly all over the worid. The beetles lay their eggs on the young pods, and the larvae, as soon as hatched, make their way through the pods into the nearest peas. They do not, as is sometimes supposed, destroy the germ, for peas will grow if they are infested, but the plant is likely to be more feeble and for this reason will not produce as large a crop as if free from the weevil.

\section{Peas marked thus $(*)$ are wrinkled.}

*GRADUS-A new English variety of the wrinkled peas; it is rery hardy, so much so that, unlike most of its type, it can be planted extremely early. The vine grows about $21 / 2$ feet high, is vigorous and very productive; the pods are large and well filled with good sized peas, seven to nine usually in a pod. The Gradus is the earliest wrinkled pea in cultivation and one of the most delicious in quality.

\section{Nott's Excelsior-The Best Early Wrinkled Pea Sold}

*NOTT'S EXCELSIOR-The Finest Dwarf Wrinkled Extra Early Variety-It is the best of recent introductions; vines are larger and more vigorous than the American Wonder, while the pods are fully one-third larger, containing six to eight fine large peas, packed so closely together in the pods that the peas are always more square than round. The pods are always well filled with peas, which in sweetness and quality have no equal, being superior to any other wrinkled sort.

*THOS. LAXTON-The only rival to the famous Gradus, as a long-podded, extreme early wrinkled pea, and in some respects even better. The growth is identical, but the pods are a deeper, richer green and square at the end. In the judgment of experts, Thos. Laxton is even sweeter and finer in flavor, while as the large peas are of a deeper green, they present a more attractive appearance on the table. 
SURPRISE OR ECLIPSE-One of the best of the new wrinkled peas. The vine grows 20 to 24 inches high, requiring no sticks. One of the most profitable sorts for the gardener to grow. Same price as Gems.

\section{Extra Early Peas \\ Special Price on Quantity}

* LITTLE MARVEL-Similar to Nott's Excelsior; better quality; height, $3 / 4$ foot. Pkt., 15c; lb., 40c.

*NOT'S'S EXCELSIOR-Height, $3 / 4$ foot. Pkt., 15c; lb., 30c.

*GRADUS-Pkt., 15c; lb., 40c.

*THOS. LAXTON-Pkt., 15c; lb., 40c

FIRST AND BEST-Early, resembling Early New Yorker. Height, 2 1/2 ft. Pkt., $15 \mathrm{c} ; 1 \mathrm{~b} ., 30 \mathrm{c}$.

ALÄSKA-One of the very earliest blue peas; quite productive. Height, $2 \frac{1}{2} \mathrm{ft}$. Pkt., $15 c ; 1 b ., 30 c$.

*AIERICAN WONDER-Nearly as early as Alaska, a good yielder, extra quality. Height, 11/4 ft., Pkt., 15c; lb., 35c.

*LITTLE GEM-McLean's very desirable early pea, great producer, good quality. Height, 11/4 ft. Pkt., 15c; 1b.,35e.

*PREMIUM GEM-Earlier than Little Gem, better quality. Height, 1 ft. Pkt., 15c; 1b., 35c.

\section{Early and Medium Peas}

*McLAIN ADVANCER-A fine standard sort of excellent quality. Height, $2 \frac{1}{2} \mathrm{ft}$. Pkt., 15c; lb., 30c.

HORSEFORD MARKET GARDEN-On the style of Advancer; very prolific. Height, $21 / 2$ ft. Pkt., 15c; 1b., 30c.

*EVERBEARING-Long pods and large peas; sow thin. Height $2 \frac{1}{2}$ ft. Fkt., 15e; lb., 30c.

*BLISS ABUNDANCE-Mediun early rine fine. Height $1 \frac{1}{2}$ ft. Pkt., 15c; lb., 30c. *TELEPHONE-Very valuable, vigorous grower, pods large, sweet. Height, $\neq \mathrm{ft}$. Pkt., 15c; 1b., 30c.

PRIDE OF THE MARKET-Pods large. Height 3 ft. ..Pkt., 15c; lb., 30c.

DVARF TELEPHONE OR DAISY-A medium late pea that needs no brushing. It is of dwarf, stock habit, healthy, vigorous growth, and productive, bearing large, handsome pods and peas of highest qualsty. Pkt., 15c; 1b., 35c.

\section{Late Peas}

Special Price on Quantity

*CHAMPION OF ENGLAND-A wellknown standard pea; sow thick. Height, 5

*YORKSHIRE HERO-A spreading ra-

ft. Pkt., 15c; 1b., 35c.

riety, very productive; sow thin. Height, $21 / 2$ ft. Pkt., 15c; lb., 35c.

MELTING SUGAR-One of the best edible pod sorts. Height 4 ft. Pkt., 15c; lb., $35 \mathrm{c}$

MAMMOTH SUGAR-Gray seed, immense edible pods. Height, 5 ft. Pkt., 15c; lb. 35c.

TALL SUGAR-White seed, edible pod. Height, 5 ft. Pkt., 15c; lb., 35c.

*DWARF WRINKLED SUGAR-Large, well-filled pods, very productive. Height $11 / 2 \mathrm{ft}$.

*STRATAGEM-The finest second early, vigorous and productive; eight to ten large peas in pod, unsurpassed in quality. Height, to $3 \mathrm{ft}$.

MARROWFAT, BLACK-EYED-The best Marrowfat. Height, 4 to $5 \mathrm{ft}$.

MARROWFAT, WHITE-An old standard sort, quality inferior, great yielder. Height, 4 to $5 \mathrm{ft}$.

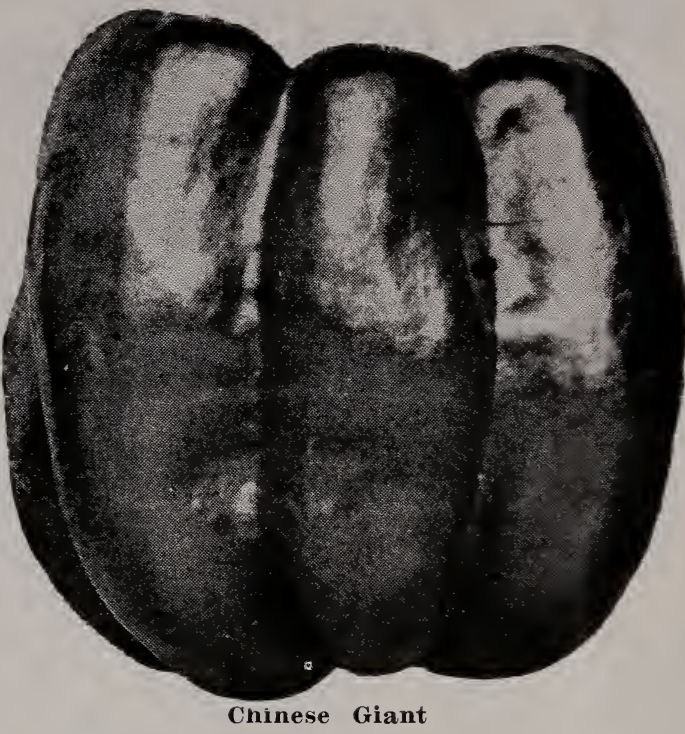

\section{PEPPER}

CULTURE-Sow in hotbeds in March, and when the soil has become warm, set in rows two feet apart and eighteen inches in the rows, hoe frequently and keep down all the weeds. The plants may also be forwarded in pots.

SWEET GOLDEN QUEEN-Very handsome and distinct and of mild flaror. Pkt., 5c; oz., 50c; 1/4-1b., \$1.50.

RUBY KING-Beautiful bright red, large fruit, mild, one of the best; fine for pickles. Pkt., 5c; oz., 45c; 1/4 lb., \$1.25.

LONG RED CAYENNE-Bright red, rery productive. Pkt., 5c; oz., 40c; $1 / 4$ lb., \$1.20.

LARGE BELL OR BULL NOSE-Large and mild, excellent for pickling. Pkt., se; oz., 45̃c; $1 / 4$ lb., \$1.25.

RED CHERRY-Cherry shaped; for pickles, for which they are largely used.

RED CLUSTER-A new type of Chili, with upright bright red fruits. Pkt., 5c; oz., 50c $1 / 4$ lb., \$1.50.

SWEET MOUNTAIN-Large, regular and of mild flaror; one of the best for pickling. Pkt., 5c; oz., 50c; 1/4 lb., \$1.25.

CHINESE GIANT (see cut)-A rery large fine, mild red pepper. Not only is it immensely productive for so large a pepper, but its enormous size and magnificent appearance make it sell most readily. The plants are vigorous in growth, well branch. ed and thickly set with enormous fruits. Fruits blocky, 4 to 5 inches broad, color brilliant scarlet. Pkt., 5c; oz., 55c; 1/4 lb., $\$ 1.60$.

\section{PARSNIP}

HOLLOW CROWN-A market garleners strain. Pkt., 5c; oz., 5c; 1/4 1b., 20c

LONG SMOOTH WHITE-Long. white, smooth, no side roots; tender and excellently flavored. Pkt., 5c; oz., 5c; 1/4 1b., 20c.

STUDENT-A half-long variety of delicious flavor. Pkt., 5e; oz., 5c; 1/4 lb., 20c. 


\section{PARSLEY}

CULTURE-Soak the seeds a few hours in luke-warm water, and sow early in the spring until the middle of July, in drills one foot apart. Thin out the plants to four inches. To preserve in winter transplant to a light cellar or cold frame.

DOUBLE CURLED-Superior. Pkt., 5c; w.., 10c; 1/4 lb., 30c.
CHAMPION MOSS CURLED-Very pretty and one of the very best. Pkt., 5c; oz. $10 \mathrm{c} ; 1 / 4$ lb., 30c.

FERX LEAVED-Fine curled. Pkt., õc; oz., 10c; $1 / 4$ lb., 35c.

HAMBURG OR ROOTED-Edible roots, much like parsnips. I'kt., 5c; oz., 10c; 1/4 lb., 3oc.

\section{PUMPKIN}

CULTURE-May be planted middle of spring, among corn or in field or garden, in hills 8 or 10 feet apart each way, 4 seeds in a hill. In other respects are cultivated in the same mauner as melons and cucumbers. Aroid planting near other vines.

LARGE CHEESE-Flat; one of the best varieties for family use; good keeper.

SWEE'T OR SUGAR-Fine grained, sweet and prolific; small yellow, best for pies. Pkt., 5e; oz., 10e; 1/4 lb., 35c.

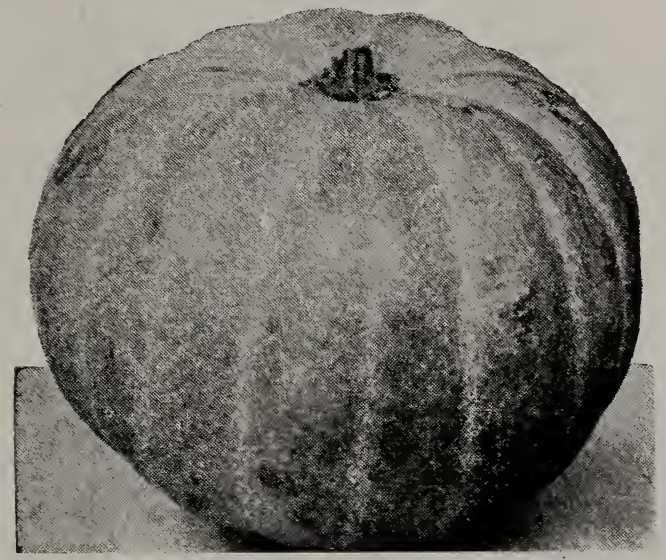

Connecticut Field
QCAKER PIE-Fine for pies, very prolific and a good keeper. Pkt., se; oz., 10c; $1 / 4$ lb., 35c

STRIPED CUSHAW-Medium size, crookneck, very productive. Pkt., 5e; oz., 10c: $1 / 4$ lb., 40c.

GOLDEN CUSHAW-Fine golden color. Pkt., 5c; oz., 10c; 1/4 1b., toc.

WHITE CUSHAW-Fine white color. Pkt., 5c; oz., 10c; $1 / 4$ lb., 40c.

MAMMOTH POTIRON-Grows to an enormous size, 150 to 275 pounds; fine for exhibition. Pkt., 5c; oz., 10c; 1/4 lb., 35c.

MAMмоTн TOCRs-A very large French variety. Pkt., 5c; oz., 10c; 1/4 lb., 35c.

TENNESSEE SWEET POTATO-Bell shaped; thick, white flesh, fine for pies. Pkt., 5c ; oz., 10c; 1/4 lb., 35̃c.

CONNECTICCT FIELD-Grown for stock; rery productive. Pkt., 5c; oz., 10c; 1/4 lb., 25c.

KENTCCKY FIELD-Grown for stock: very productive. Pkt., 5e; oz., 10c; $1 / 4$ lb., 20c.

\section{RAPE \\ Dwarf Essex}

A most profitable forage plant. We an think of no more simple change which would do more to increase the profitableness of American farming than a more general use of Dwarf Essex Rape. It is an inexpensive crop, costing but little for seed or cultivation, is very hardy, can be made to take the place of some crop that has failerl, and will yield an enormous crop of foralge, or it can be sown after the harrest as a cover crop, and, when fed off by stock, particularly sheep, will rapidly restore the fertility of the exhausted soil. It is important that the true biennial Dwarf Essex Rape should be used, and not the annual sort, which is not only much less valuable as a crop, but which when once introduced, becomes a pernicious weed rery difficult to eradicate.

MANY FARMERS are sowing Dwarf Essex Rape with their wheat or other spring sowing crops, putting it right in the drills with the grains sown. The Rape plants do not derelop sufficiently to interfere with the growing grain, but after harrest comes on rapidly. It does well to sow after the corn has been laid by and when the corn has been husked it furnishes the very best pasture in connection with the stalks. Lb., $15 c$; 5 lbs., 70c: 12 lbs., \$1.50; 25 lbs. and over 12c per lb. For larger lots write for special prices.

\section{RHUBARB}

MAммотH-Very large. but good qualit $y$. Pkt., 5c; oz., 15c; $1 / 4$ ib., 40c.

LINNAEUS-The earliest. Pkt., 5c; oz., $15 \mathrm{c} ; 1 / 4$ 1b., $40 \mathrm{c}$
VICTORIA-Very fine in quality, but small. Pkt., 5c; oz., 15c; 1/4 lb., 40c.

ROOTS-Per do\%, 60c; per $100 \$ \$ .00$. 


\section{RADISH}

Ready for use from 18 to 25 days.

CRIMSON GIANT-This we consider the greatest new radish in the last ten years. It is of American origin. It is an early radish, looking much like the old Early Scarlet globe, but more perfect in shape and color. It comes as early as any radish, but the amazing thing about it is that it keeps on growing and remains tender, solid and sweet, till it gets as large as a teacup or larger. Just imagine the nicest Scarlet Globe Radish you ever saw, deep red outside and pure white inside, fine flavor, and as large as a teacup and you will have a good idea of it.

CRIMSON GIANT-Pkt., 5c; oz., 10c; 1/4 lb., 30c.

TURNIP EARLY SCARLET-Very early, crisp; good forcing. Pkt., 5c; oz., 10c; $1 / 4$ lb., 30c.

TURNIP EARLY DEEP SCARLETVery early; used for forcing. Pkt., 5c; oz., $10 \mathrm{c} ; 1 / 4$ 1b., 30c.

TURNIP EARLY SCARLET WHITE TIPPED-Very early, for frames or outdoors. This is one of the best for market gardeners. Pkt., 5c; oz., 10c; $1 / 4$ lb., 30c.

FRENCH BREAKFAST-Earliest, most handsome, tender and crisp. Deep, glossy crimson with white tips. Pkt., 5c; oz., 10c; $1 / 4$ 1b., 30c.

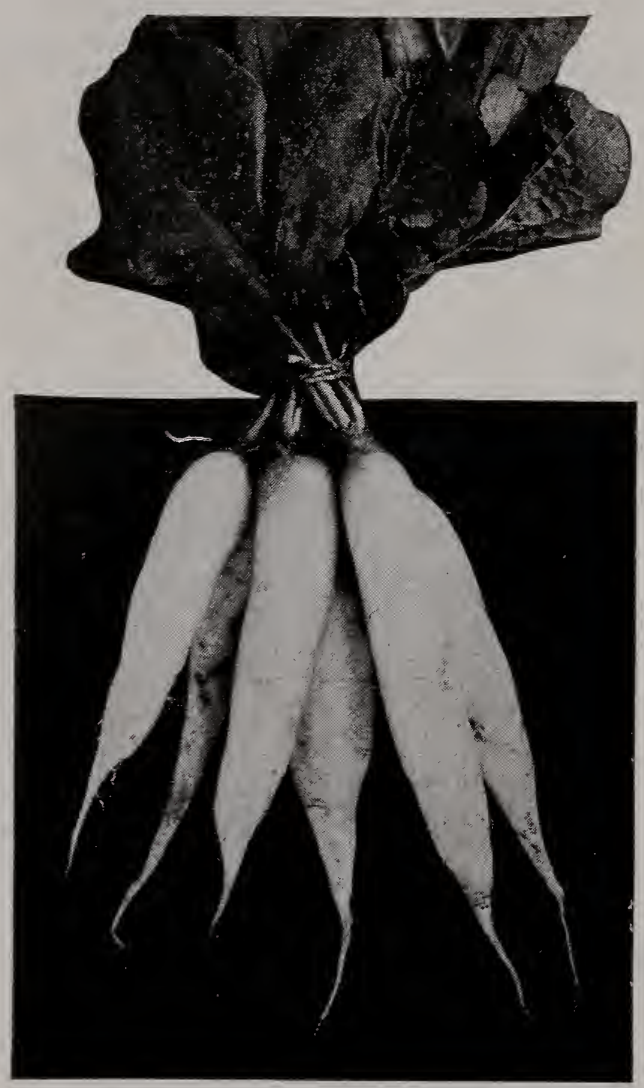

White Icicle

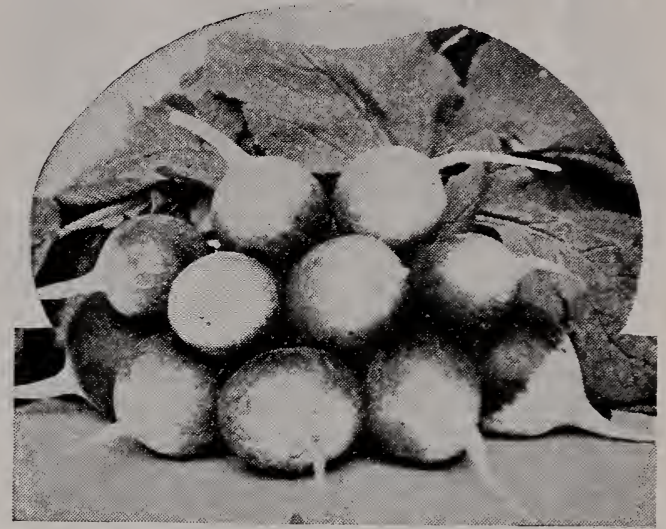

Crimson Giant

*ROSY GEMI-One of the very best for market gardeners: very early, tender, beautiful scarlet, shading off into a white tip. Pkt., 5c; oz., 10c; 1/4 lb., 30c.

*TURNIP EARLY DEEP BLOOD RED -Extra early forcing sort. Pkt., 5c; oz. 10c; $1 / 4$ 1b., 30c

*TURNIP EARLY WHITE OR BOXSuitable for forcing, fresh, pure white and sweet. Pkt., 5c; oz., 10c; 1/4 lb., 30c.

*LONG SCARLET SHORT TOP-Very long and crisp, for frames and open ground. Pkt., 5c; oz., 10c; 1/4 1b., 30c.

*LONG BRIGHTEST SCARLET-White tipped, very bright and beautiful. Pkt., כe; oz., 10c; $1 / 4$ lb., 30c.

*LONG SCARLET CHARTIER WHITE TIPPED-Shades from crimson to white; tender. Pkt., 5c; oz., 10c; 1/4 1b., 30c.

LONG WHITE VIENNA OR LADY FINGER-Crisp and tender in summer; one of the best. Pkt., 5c; oz., 10c; $1 / 4$ 1b., 30c.

*THE ICICLE-A new introduction of the Long White; beautiful ivory white color; fine, slender form, quality excellent; very early: fine for market. Pkt., 5c; oz., 10c; $1 / 4$ lb., 30c.

*WHITE STARSBURG SUMMER-Very large; the German's favorite; quality fine. Pkt., 5c; 0z., 10c; 1/4 lb., 30c.

WHITE STUTTGART SEMMER-Very early and very large. Pkt., 5c; oz., 10c; $1 / 4$ lb., 30c.

*WINTER ROSE CHINA-Tery handsome and distinct and keeps well. Pkt., 5c; oz., 10c; $1 / 4$ 1b., 30c.

WINTER ROCND BLACK SPANISHFine for winter. Pkt., 5c; oz., 10c; 1/4 1b., 30c.

IVINTER LOYG BLACK SPANISHThe popular winter sort. Pkt., 5c; oz., 10c; $1 / 4$ 1b., 35c.

WINTER CALIFORNIA WHITE MAMМотн-A very large white winter variety. Pkt., 5c; oz., 10c; 1/4 1b., 30c. 


\section{SALSIFY, or Vegetable Oyster}

LONG WHITE FRExCH. .Pkt., 5e; oz., $20 c ; 1 / 41 b ., 75 c$.

MAMMOTH SANDWICH ISLAND-Large

\section{SPINACH}

VIROFLAY THICK LEAVED-Has very large and thick leares. Pkt., 5c; oz., 5e; 1/4 lb., 20c.

CURLY LEAVED SATOY OR BLOOMSDALE-Large, tender leaves, fine. Pkt., 5c; oz., 5c; $1 / 4$ lb., 15c.

LONG STANDING ROUND THICK LEAVED-Dark green, rery long standing before running to seed. Pkt., 5e; oz., 5c; 1/4 1b., 20c.

PRICKLY-Vigorous and hardy. Pkt., 5e; oz., 5c; $1 / 4$ lb., 20c.
NEW ZEALAND-Entirely different from the tree Spinach in type and in that it thrires during hot weather and in any soil, rich or poor. The tender shoots are of good quality and may be cut throughout the summer. Plant three or four seeds in hills two feet apart each way. This Spinach can be used in August or September or up till frost. By using only the leares it will sprout out again. Pkt., 5e; oz., 5e; 1/4 lb., 20c.

\section{SQUASH}

DELICIOUS- This is a fall and winter variety of medium size. Although not rery thick, the shell is rather hard and strong. Usually dark green but sometimes lighter in color and mottled. The flesh is thick, rery fine grained and bright yellow in color. It is considered by many to be the best for markets where quality is appreciated as well as very desirable for the home garden. We have by continued and careful selection made a marked improrement in uniformity of type and we believe the seed we offer is equal to the best abtainable. Pkt., 5c; oz., 15c; 2 oz., 25c; $1 / 4$ 1b., 45c; $1 \mathrm{~b} ., \$ 1.60$.

EARLY GO L D E N BUSH SCALLOP-Fine for summer use, not as early as the White. Pkt., 5c; oz., 20c; 1/4 lb., 50c.

EARLY W H I T E S C A L LOP BUSH-A good early shipping variety, best scallop. Pkt., 5c; oz., 20c; 1/4 lb. 50c.

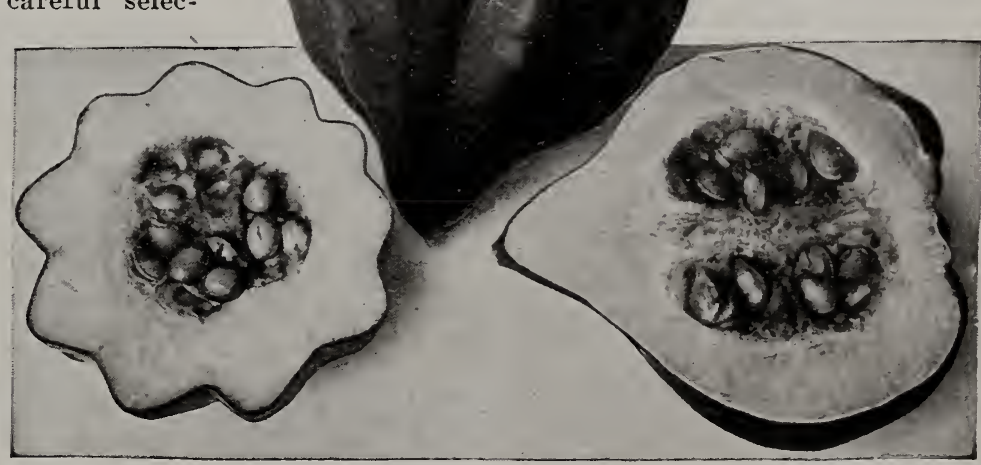

GOLDEN SUMMER CROOKNECK-ONe of the very best summer squashes. Pkt., 5c; oz., 20c; $1 / 4$ lb., 50c.

EARLY ORANGE MARROW-An IMproved Boston marrow; quite distinct, very early and of most delicious flaror; suitable for fall or winter. Pkt., 5c; oz., 20c; $1 / 4$ 10., ove.

BOSTON MARROW-Oval, bright orange, flesh yellow and fine. Pkt., 5c; oz., 10c; $1 / 4$ lb., 50c.

HUBBARD-Well known and liked for late use; of superior quality. Pkt., 5c; oz., $15 \mathrm{c} ; 1 / 4 \mathrm{lb} ., 65 \mathrm{c}$.

WARTY HUBBARD-More warty, harder shell, better keeper, true stock. Pkt., 5c; oz., 15c; $1 / 41$ b., 75c.

RED OR GOLDEN HUBBARD-Fine reddish or golden color, large size, fine quality. Pkt., 5e; oz., 15c; $1 / 4$ lb., 60c.

BAY STATE-With hard, blue shell, for fall and winter. Pkt., 5c; oz., 15c; 1/1 1b., 50.

PIKE'S PEAK OR SIBLEY-Thick, bright orange flesh, fine winter sort. Pkt., 5e; oz., 15c; 1/4 1b., 50c.

\section{Delicious}

FORDHOOK-One of the best winter squashes; fine quality, bright yellow. Pkt., 5c; oz., 15c: $1 / 4$ lb., 50c.

MAMMOTH CHILI-Grows to an enormous size; rich, orange yellow. Pkt., 5e; oz., $15 \mathrm{c} ; 1 / 4$ lb., $50 \mathrm{c}$

IARBLEHEAD-Resembling the Hubbard, but has gray skin. Pkt., 5e; oz., 15e; $1 / 4$ lb., 50c.

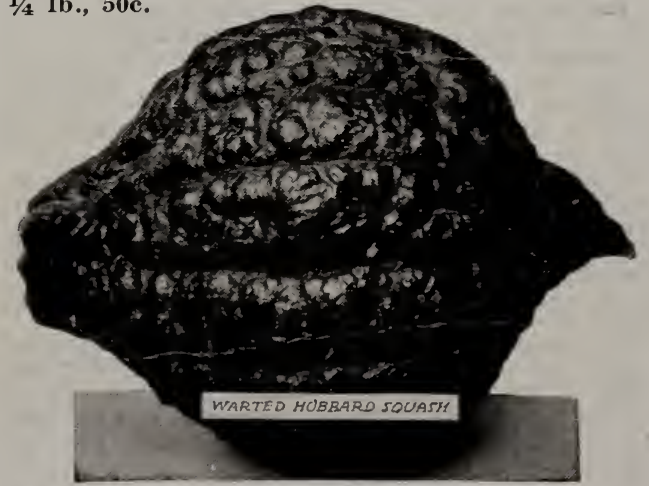




\section{TOMATO}

CHALK'S EARLY JEWELL-An extremely early variety of brightest scarlet color, deep fruited and solid. Very few seeds and of excellent flavor. Pkt., 5c; oz., $25 \mathrm{c} ; 1 / 4$ lb., $\$ 1.00$.

EARLIANA-It is a full week ahead of all others. Plants of strong growth and very productive. Fruits large, deep red, and of superior quality. Smooth and free from cracks. Pkt., 5c; oz., 25c; 1/4 1b., \$1.00.

MATCHLESS-Extra large, smooth and handsome; bright red, very solid. Pkt., 5c; oz., 20c; $1 / 4$ lb., 75c.

PONDEROSA-The largest variety in cultivation. Pkt., 5c; oz., 40c; 1/4 lb., \$1.50.

BONNEY BEST-Very early, scarlet fruit. Vines vigorous; exceptionally good quality.

DWARF CHAMPION-Quite distinct in foliage and habit of growth, being compact and upright. Fruits early and resembles Acme in appearance. Pkt., 5c; oz., 30c; 1/4 lb., \$1.00.

PERFECTION (Livingston)-Early, regular and productive, red, heavy cropper. Pkt., 5c; oz., 20c; 1/4 lb., 75c.

FAVORITE (Livingston)-Large, smooth, productive and good shipper. Pkt., 5c; oz., 25e; $1 / 4$ lb., 75c.

BEAUTY (Livingston)-Large, smooth, pinkish red, thick flesh, regular form. Pkt., 5c; oz., 25c; 1/4 lb., 75c.

STONE (Livingston)-Very large, perfectly smooth, fine bright scarlet; best main crop. Pkt., 5e; oz., $20 ; 1 / 4$ lb., 60c.

ACME-Medium red, smooth and good; one of the best varieties. ETAOINSHRD one of the best eariies. Pkt., 5c; oz., 20c; $1 / 4$ lb., 70c.

EARLY ADVANCE-Bright red, medium sized, smooth, solid, very early. Pkt., 5c; oz., 20c; $1 / 4$ lb., roc.

ROYAL RED-A first class main crop variety; skin and flesh intense red. Pkt., 5c; oz., 20c; $1 / 4$ lb., 70c.

TROPHY, LARGE-Very solid, standard late sort, grown extensively for canning. Pkt., 5c; oz., 20c; 1/4 lb., 75c.

YELLOW PLEM-Round and regular, bright yellow; used for pickles. Pkt., 5c; oz., 35c; $1 / 4$ lb., $\$ 1.00$.

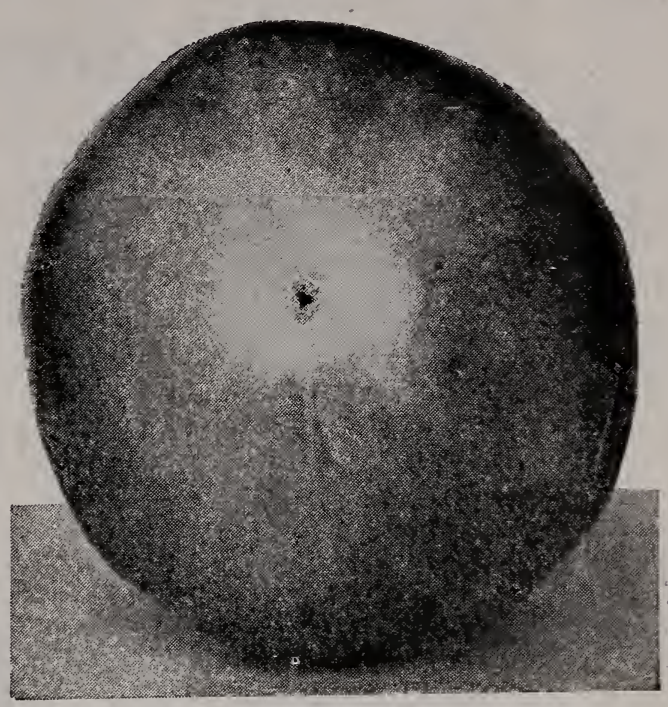

Earliana

PEACH-Resembles a peach, for preserves, pickles and exhibition; quality excellent. Pkt., 5c; oz., 30c; 1/4 lb., \$1.00.

YELLOW PEACH-Very handsome in form, and of a beautiful clear yellow color; is useful to contrast with other sorts. Pkt., 5c; oz., 30c; $1 / 4$ lb., $\$ 1.00$.

RED CHERRY-Fruit about an inch in diameter in bunches; used for pickles. Pkt., 5c; oz., 30c; $1 / 4$ lb., $\$ 1.00$.

RED PEAR-SHAPED-Fruit of peculiar shape, handsome and solid. Pkt., 5c; oz., 35c; $1 / 4$ lb., \$1.00.

GROUND CHERRY (Husk Tomato)Small and ornamental fruit used for preserves. Pkt., 5c; oz., 30c; 1/4 lb., \$1.00.

GOLDEN QUEEN-Large size, handsome, very smooth, good quality. Pkt., 5c; oz., $20 \mathrm{c} ; 1 / 4$ lb., $75 \mathrm{c}$.

\section{TURNIP}

EARLY MHLAN WHITE-Vtry early, white top. Pkt., 5c; oz., 10c; $1 / 4$ lb., 35c.

EARLY MILAN WHITE-Very early, all ; with purple top. Pkt., 5c; oz., 10c; 1/4 lb., $35 \mathrm{c}$.

WHITE EGG-Oval, handsome and sweet. Pkt., 5c; oz., 10c; 1/4 lb., 30c.

CARLY DUTCH-Rather flat; good white early sort. Pkt., 5c; oz., 10c; ' $1 / 4$ 1b., 30c.

Cow HORN-Early and good; shaped like a Nantes carrot. Pkt., 5c; oz., 10c; 1/4 lb., 25c.

PURPLE TOP STRAP LEAF-The popular flat fall sort; sweet, firm and mild. Pkt., 5c; oz., 10c; $1 / 4$ lb., 25c.

PURPLE TOP WHITE GLOBE-A standard sort in the New York market; nothing better. Pkt., 5c; oz., 10c; 1/4 lb., 25c.

POMERANIAN White GLOBE-Large, good for both table and stock. Pkt., 5c; oz., 10c; $1 / 4$ lb., 25c.

WHITE NORFOLK-Globular, late, solid, very large, fine for stock. Pkt., 5c; oz., 10c; $1 / 4$ lb., 25c.
WHITE STRAP LEAF FLAT-A good early white flat sort. Pkt., 5c; oz., 10c; 1/4 lb., 30c.

WHITE GLOBE-Good either for table or stock; one of the best. Pkt., 5c; oz., 10c; $1 / 4$ lb., 25c.

YELLO IW GLOBE-Good and sweet; keeps fairly well. Pkt., 5c; oz., 10c; 1/4 lb., 30c.

GOLDEN BALL OR ORANGE JELLY -Very handsome; keeps fairly well. .Pkt., 5сc; oz., 10c; 1/4 lb., 25̃c.

SNOWBALL OR SIX WEEKS-A very rapid growing, small variety that will mature in forty days from sowing of seed. Flesh sweet and tender. Pkt., 5c; oz., 10c; $1 / 4$ lb., 30c.

SWEET GERMAN-White, hard, firm, sweet; must be sown early; partakes of the nature of Ruta Baga. Pkt., 5c; oz., 10c; 1/4 lb., 30c.

YELLOW ABERDEEN-Hardy, productive and a good keeper. Pkt., 5c; oz., 10c; 1/4 lb., 30c. 


\section{RUTABAGA}

\section{or Swedish Turnip}

MONARCH-Distinct in form; a grand, good variety; very large yielder; grown mostly above the ground; flesh rich yellow. Pkt., 5c; oz., 10c; 1/4 lb., 30c.

IMPROVED AMERICAN PURPLE TOP -Very hardy variety; flesh yellow, sweet and well flavored; deep purple; has but little neck. Pkt., 5c; oz., 10c; 1/4 lb., 25c.
CARTER'S IMPERIAL HARDY-A purple topped variety, growing to a large size, single to root; good flavor. Pkt., 5e; oz., 10c; $1 / 4$ lb., 30c.

WHITE SWEED OR RUSSIAN-EXcellent variety for either table or stock; white flesh, fine flavor, good keeper. Pkt., 5c; oz., 10c; 1/4 lb., 25c.

\section{AROMATIC, MEDICINAL AND POT HERBS}

\section{GENERAL CULTURE DIRECTIONS}

Most of the rarieties thrive best on a rich sandy soil, which should be carefully prepared and well cultivated, as the young plants are for the most part delicate and easily choked out by weeds. Sow as early as the ground can be made ready, in drills sixteen to eighteen inches apart, taking pains that the soil is fine and pressed firmly over the seed, or they may be planted as a second crop, the seeds sown in beds in April and the plants set out in June. Most of them should be cut when in bloom, wilted in the sun and thoroughly dried in the shade.

ANISE-A well-known annual herb, whose seeds, which have an agreeable aromatic odor and taste, are used for dyspepsia and colic and as a corrective for griping and unpleasant medicines. Sow early and thin to three inches apart in the row. Oz., 10c; $1 / 4$ Ib., 30c; lb., \$1.00.

BALM-A perennial herb, easily propagated by division of the root or from seed. The leaves have a fragrant odor, similar to lemons, and are used for making balm tea for use in fevers and a pleasant beverage called balm wine. Plant early and thin to ten inches apart. Oz., 25c; 1/4 lb., 75c; 1b., $\$ 2.50$.

BASIL, SWEET-A hardy annual from the East Indies. The seeds and stems have the flavor of cloves and are used for flavoring soups and sauces. Oz., 15c; 1/4 lb., 40c; lb., \$1.50.

CARAWAY-Cultivated for its seed, which is used in confectionery, cakes, etc. The leares are sometimes used in soups. If sown early in August, the plants will gire a fair crop of seed the next season, but when sown in the spring will not seed until the next year. Plant in drills two or three feet apart and thin to six inches apart in the row. Oz., 10c; $1 / 4$ lb., 25c; lb., 75c.

CARAWAY FOR FLAVORING-Oz., 10c; 2 ozs., 15̃c; 1/4 lb., 20c; lb., 50c.

CAT MINT OR CATNIP-A hardy perennial, well known as a valuable mild nervine for infants. The plants should be pulled up by the roots when in full flower and dried in the shade. The seed may be sown either in the fall or early spring, in drills, twenty inches apart. Oz., 30c: 1/4 1b., \$1.00; 1b., \$3.00.

CORIANDER-A hardy annual, cultivated for its seed, which has an agreeable taste, and is used in confectionery and to disguise the taste of medicine. Sow early in the spring and gather on a dry day, bruising the stems and leaves as little as possible. Oz., 10c; $1 / 4$ lb., 25c; 1b., 75c.

CORIANDER FOR FLAVORING-Oz. $10 c$; 2 ozs., 15c; $1 / 4$ lb., 20c; lb., 75c.

DILL-An annual, cultivated for its seed, which has an aromatic odor and

warm, pungent taste. It is good for flatulence and colic in infants and is sometimes added to pickled cucumbers to heighten the flavor. Sow early in spring and keep clear of weeds. Oz., 10c; $1 / 4$ lb., 20c; 1b., 60c.

MARJORAM, SWEET-A perennial plant, but not hardy enough to endure the winters of the north. The young, tender hops are used green for flavoring or they may be dried for winter use. Sow in drills as early as possible, and thin out the plants to ten inches apart. Oz., 15c; 1/4 lb., 40c; 1b., $\$ 1.25$.

ROSEMARY-A hardy perennial, with fragrant odor and a warm, bitter, aromatic taste. May easily be raised from seed, but does not reach a size fit for use until the second season. The dry leaves deteriorate rapidly with age. Oz., 40c; 1/4 lb., \$1.25; lb., $\$ 4.00$.

RUE-A hardy perennial with a peculiar smell. The leares are bitter and so acrid as to blister the skin. It is a stimulant and anti-spasmodic, but must be used with great caution, as the use sometimes results in serious injury. It must not be suffered to rum to seed and does best on poor soil. Oz., $15 \mathrm{c} ; 1 / 4$ lb., 40c; lb., \$1.50.

SAGE-A hardy perenuial, possessing some medicinal properties, but cultivated principally to use as a condiment, it being used more extensively than any other herb for flavoring and dressing. Sow early in spring (four to five pounds per acre in drills) on very rich ground; cultivate often and thin the plants to sixteen inches apart Oz., 45c; $1 / 4$ lb., $\$ 1.50 ; 1 b ., \$ 6.00$.

SUMMER SAVORY-A hardy annual, the dried stems, leaves and flowers of which are extensively used for flavoring. particularly in dressings and soups. Cultivate the same as Sweet Marjoram. Oz., 10c: 1/4 lb. $30 c ; 1 b ., \$ 1.00$

THIME-This herb is perennial and is both a medicinal and culinary plant. The young leaves and tops are used for somps, dressings and sauce; a tea is made from the leaves, which is a great remedy in nervous headache. Sow as early as the ground will permit. Oz., 20c; $1 / 4$ lb., 60e; lb., 82.00 . 


\section{SWEET PEAS}

OUR SWEET PEAS ARE UNSURPASSED FOR PURITY OF STRAIN, NOTHING BET-

TER IN THE U. S. THEY HAVE GIVEN WONDERFUL SATISFACTION THE PAST YEAR. IF YOU BUY OURS YOU BUY THE BEST.

The following varieties are selected with a view to please the most critical, and we think the Cream of the List of Sweet Peas:

\section{LIGHT SHADES OF PINK}

DUCHESS OF YORK-Standard and wings large and of fine form. White overlaid with a lacing of exceedingly delicate pale pink.

ELIZA ECKFORD-Large flower of rosy pink over white, giving an exceedingly delicate and beautiful effect.

KATHERINE TRACY-The color is soft but brilliant pink, of the same shade in wings.

LOVELY-A delicate shell pink tinged with yellow, producing a very warm, soft color of exceeding beauty.

PRIMA DONNA-The stems bear three or four very large, perfect flowers, of exceeding beauty.

RAMONA-Large, finely formed flower; standard and wings white, but nearly covered with a very warm pink in small dots and shades.

VENUS-Standard large, of fine form and substance; a brilliant but delicate and soft shade of warm rose-pink and buff.

\section{DARKER SHADES OF PINK}

APPLE BLOSSOM-Standará rose-pink, lighter at the edges; wings lighter than standard.

HER MAJESTY-The flowers are very large, a delicate rose-pink color.

LADY MARY CURRIE-A large, wellformed flower of brilliant orange-pink color.

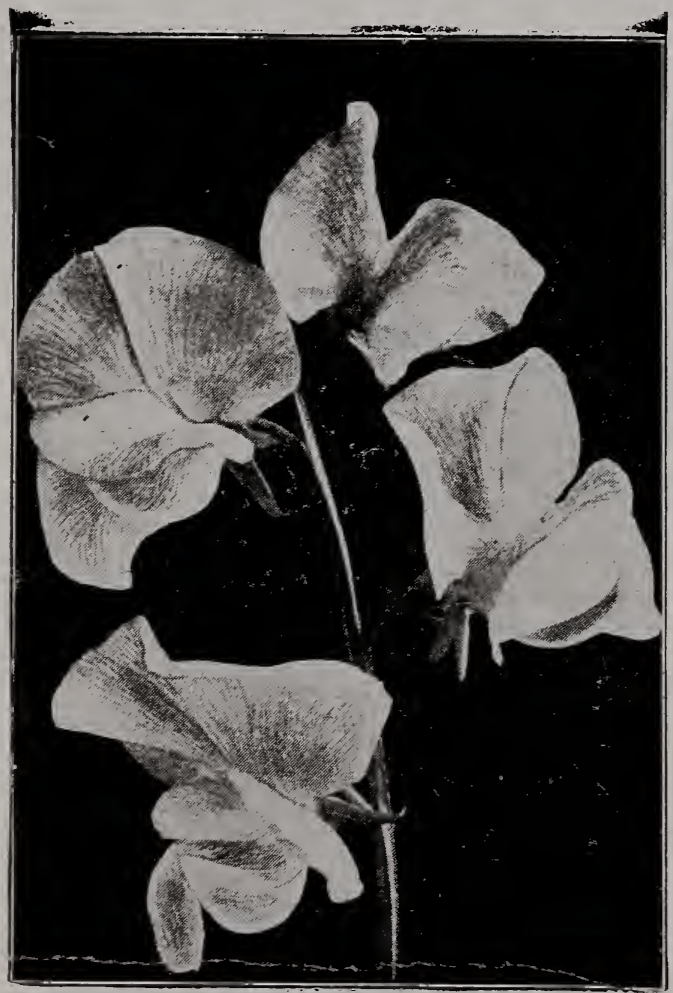

Sweet Peas
OVID-A good-sized, hooded flower of bright pink, overlaid with a darker shade.

LADY PENZANCE-A large and striking flower of a peculiar and beautiful shade of rose-pink, with a slight tinge of orange.

PEACH BLOSSOM-A very large flower, having a warm yellowish-pink standard and wings of a lighter, softer shade.

ROYAL ROSE-One of the largest and finest formed flowers yet produced. Standard a deep rose-pink.

Red or rose standards with lighter wings.

BLANCH SHADES OF RED sized, but of fine form and bright pink color; wings large, rounded and nearly white.

BRILLIANT-Flower of good size and substance, color very brilliant rich red.

FIREFLY - Very bright, and intense crimson, scarlet of good size and form.

MRS. DUGDALE-A large, finely formed flower of a peculiar shade of primrose overlaid with crimson rose.

SALOPIAN-One of the most brilliant and most richly colored sorts yet introduced.

\section{CLARET AND MAROON}

DUKE OF CLARENCE-A fine flower with large standard and wings of uniform shade of dark claret.

MONARCH-Standard large, fine form, violet maroon, wings very large and expanded.

SHAHZADA-This has a very rich, dark maroon standard and deep violet wings; one of the finest dark sorts.

\section{LIGHT YELLOW}

PRIMrosE-Standard medium sized rather long, yellowish white in front, and pronounced primrose-yellow on the back.

STELLA MORSE-The large flowers of this variety are of the finest form and a peculiar warm salmon-pink.

COQUETTE-Large, finely formed flower. Standard warm primrose with a shade of purple.

ORIENTAL-The large, finely formed flowers are a distinct bright orange of a very brilliant and striking shade.

\section{STRIPED OR VARIEGATED}

AMERICA-White, nearly covered with splashes, stripes and dots of exceedingly bright carmine; the most brilliant of the red striped sorts.

AURORA-The standard and wings are striped and flaked with delicate orange-salmon, pink over white.

GRAY FRIAR-Very large, finely shaped flowers of delicate heliotrope color, peculiarly tinged, marbled and dotted with darker shades.

JUANITA-Large and splendidly formed; white, with stripes and dashes of delicate lavender.

LAVENDER AND LIGHT BLUE

COUNTESS OF RAD NOR-Self-colored in a very distinct and beautiful shade of lavender.

DOROTHY TENNANT-Flowers warm violet or mauve, very large and finely formed. LADY GRISEL HAMILTON-A large flower similar in color to the Countess of Radnor, but is nearly blue. 


\section{SWEET PEAS (Continued)}

LOTTIE ECKFORD-Standard a peculiar and delicate shade of magenta blue.

MAID OF HONOR-Medium sized flower nearly white, having a distinct edging of blue.

\section{BLUE AND PURPLE}

BLACK KNIGHT-The darkest variety. COUNTFS OF CADOGAN-A variety having very long stems, each bearing three or four flowers.

CAPTAIN OF THE BLUES-Standard large, broad, bright purple blue; wings expanded, lighter and brighter blue than standard. tinct.

NAVY BLUE-A true blue, quite dis-

\section{WHITE}

BLA NCHE BURPEE-A splendid pure white variety. While not so profuse a bloomer or as hardy a plant as the Emily Henderson, the individual flowers are so fine as to make it a most desirable sort.

EMILY HENDERSON-A bold, wellformed, clear white flower. Wings broad and well expanded. An early and wonderfully free and persistent bloomer.

THE BRIDE-The flowers are practically the same as the Blanche Burpee, but the stems are more slender.

MRS. JOSEPH CHAMBERLAIN-Very large and perfect shaped flowers; white, striped with bright rose carmine.
PRINCESS OF WALES-Standard broad, flat, striped purple on nearly white ground; wings very large and lighter than standard.

\section{MIXTURES OF SIVEET PEAS}

CHOICE MIXED-One of the most satisfactory ways of growing sweet peas is in a mixed row. Many new combinations are obtained by cross-fertilization, and if good varieties are planted, the result is sure to be satisfactory. Our Choice vixture has no superior; it is not composed of refuse stocks, but contains the finest known American kinds.

ECKFORD'S HYBRIDS, MIXED-This is made up of the best of Eckford's large flowering sorts, carefully proportioned. As only Eckford's varieties are used in this mixture, some of our very best sorts are necessarily excluded; but it will give large, finely formed flowers in a great variety of beautiful colors.

\section{PRICES ON SWEET PEAS}

NAMED VARIETIES-As above. Pkt., $5 c ; 1 / 41 b ., 60 c$.

FANCY MIXED-Made up by us from the above fifty-three varieties. Pkt., 5c; $1 / 4$ 1b., 40c.

FINEST MIXED-As grown in the field. Pkt., 5c; 1/4 lb., 35c.

ECKFORD'S HYBRIDS, MIXED-Pkt. 5c; $1 / 4$ lb., $40 \mathrm{c}$

The Fancy Hixed that we make up from the fifty-three varieties, as described above, is something superb and charming, and will please the most fastidious.

\section{GRASS AND FIELD SEED DEPARTMENT} OUR SEEDS ARE UP TO STANDARD OF THE PURE SEED LAW OF THE STATE OF IOWA

We do not deem it necessary to enter into an extended description of this branch of our business. In brief we only wish to say that at all seasons of the year we are prepared to furnish as choice a line of GRASS SEEDS and FIELD SEEDs as any market in the West. With our superior milling facilities we are prepared to reclean and grade all classes of seeds and put them on the market in the very best shape.

THERE ARE NO SEEDS OFFERED THAT ARE FREER FROY TOUL SEED THAN OURS. OUR PRICES WILL BE FOUND AS LOW AS ANY IN THE NORTHWEST.

Anything in the above line you have to offer, send us a good sized sample by mail and we will make you highest market price.

WE CARRY ALFALFA, ALSIKE, BUCKWHEAT, KENTUCKY BLUE GRASS, ENGLISH BLCE GRASS, BROMUS INERMIS, CLOVER, SWEET CLOVER, DWARF ESSEX RAPE, LAWN GRASS, ORCHARD GRASS, RED TOP, RYE GRASS, SUNFLOWER, SPELTZ OY EMMER.

We Want to Buy anything in the above line you have to offer. Send us a good sized sample by mail and we will make you the highest market price.

\section{CLOVERS AND GRASSES}

The Clover and Grass Seed we handle are clean and free of all foul and obnoxious weed seed. We invite every one interested to call and inspect our stocks before buying elsewhere.

ALFALFA CLOVER-This grand Clover forage plant is now a success everswhere. Every farmer has either heard of or knows its worth and merit. The plant grows, thrives and does well on any of our rolling prairies or well-drained bottom lands. The vigorous roots searching for moisture sink deep into the ground, bringing to the surface the fertilizing materials stored in the earth for ages, leaving the land richer and better for succeeding crops than when it was first sown. Three crops are often cut in one season, and from ten to twelve tons of excellent has is the annual reward. One bushel of 60 pounds will sow three acres. It should not be cropped or pastured the first year. Can be planted with a light nurse crop of barley, speltz or wheat. The stock we handle is the very best of hardy northern-grown seed. We offer at present some choice Western-grown seed and importd seed at prices ranging from $\$ 8$ to $\$ 9$ per bushel, subject to market changes.

IEUIUM RED CLOVER-This is by far the most important of all the varieties for practical purposes. Sow in spring or fall, and if no other grasses are used, at the rate of 15 pounds per acre; more is used on old soil than on new.

Alsike, or Swedish Clover-The most hardy of all clovers. On rich, moist soil it yields an enormous quantity of hay or pasturage, but its greatest value is for sowing with other clovers and grasses, as it forms a thick bottom and greatly increases the yield. The heads are globular, fragrant and much liked by bees, which obtain a large amount of honey from them. Sow in spring or fall, at the rate of 10 pounds per acre, when used alone. 


\section{GRASS AND FIELD SEEDS (Continued)}

BROMUS INERMIS (Awnless Brome Grass)-A hardy perennial, standing extremes of heat, cold and drouth better than any other of our cultivated grasses. Is especially adapted to the Northwest. It grows with great rapidity and produces heavy hay crops and luxuriant pastures. All kinds of stock eat it greedily, and the analysis made shows that it is exceedingly rich in flesh-forming ingredients. Sow about 15 to 20 pounds to the acre.

KENTUCKY BLUE GRASS-The universal pasture grass of America and the finest lawn grass in the world is our own Kentucky Blue Grass. It starts like magic with the first smile of spring, and is a velvet of green until winter comes again. It can be sown on the wild prairie and will catch, but the best results are to be had by getting the seed well covered. The seed we offer comes directly from Kentucky in car lots and is fresh, clean and pure.

ENGLISH BLUE GRASS (Meadow Fescue)-In just a few years this grass has come to the front like magic. This is due to the fact that it is a success everywhere on all kinds of land and never freezes out. It comes early in the spring, is green all summer and lasts until late autumn. It's a nutritious pasture and a valuable hay crop, too. It's a perennial. 'Two to three feet high, and heads out in June.

WHITE CLOVER-A small perennial variety, valuable for pasturage and for lawns. It accommodates itself to a variety of soils, and can be grown anywhere. Can be used to great advantage in pasturing mixtures. Sow in spring, at the rate of eight to ten pounds per acre, or when used with other grasses, half that amount.

RED TOP-This grass is especially suited to low, wet, spouty lands; is, in fact, the only grass which is a real success on such soil. It stands our northern winters, can be sown on wet land without cultivation, and will catch. Into the wet soil it spreads its network of roots, tames the land and in a few years makes a deep substantial sod.

GERMAN MILLET-Of all the different kinds of grass and forage plants raised for either hay or pasture, Millet is the most widely known and extensively used. If drouths wither and rain and floods drown out and destroy the early planted fields of grain, Millet is the farmer's next resort. The Pure German Millet, of all the well-known kinds, is by far the most valuable. This well-known sort reaches the acme of perfection in the more southern states and it is a fact that when the southern grown seed is planted in the north it produces a taller stalk and heavier growth of foliage than can possibly be raised from our own northern-grown seed. It is the judgment of those who have tried the seed from both sections side by side, the planter had better pay $\$ 2.00$ per bushel for pure, southern-grown German Millet than to have the other as a gift.

SORGHUM (Sugar Cane for Fodder)The greatest of all forage and fodder plants. It will yield two crops of fodder and a good fall pasture in one season. Roots deep into the subsoil and stands the drouths that often destroy other crops. As a rough provender it is unsurpassed. Sow one to two bushels per acre.

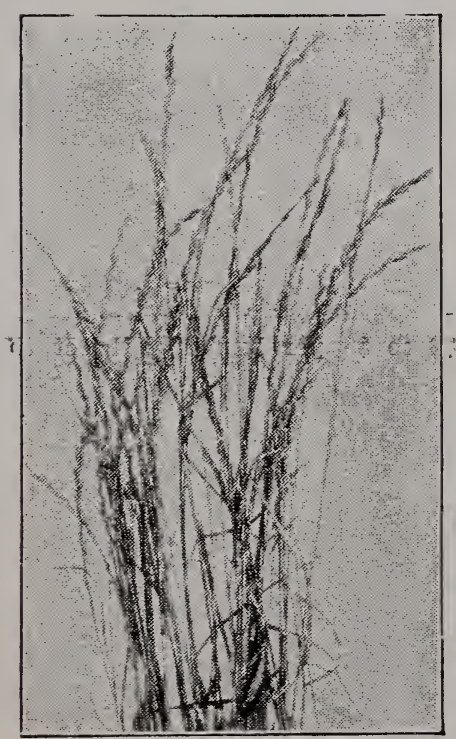

Red Top
ITALIAN RYE GRASS -This grass, though but an annual in this climate, produces such great results that in a very short time after the seed is sown it miakes as fine a pasture as other grasses of long standing. It grows about two to three feet high. The leaves are very dark green with a rich tint to the blade. It makes a pasture quick as oats, wheat, barley or rye would, and being a grass is. of far greater value. 'It - makes a splendid winter pasture if left to cure on the ground.

ORCHARD G RA S S This grass does well everywhere, and for hay can be cut much earlier than timothy. Succeeds the best of all grasses in timbered lands or orchards. Sow one to two bushels per acre.

TIMOTHY - This wellknown grass is the best of all grasses for hay. Succeeds very well on all kinds of soil, but is well adapted to moderately moist land.

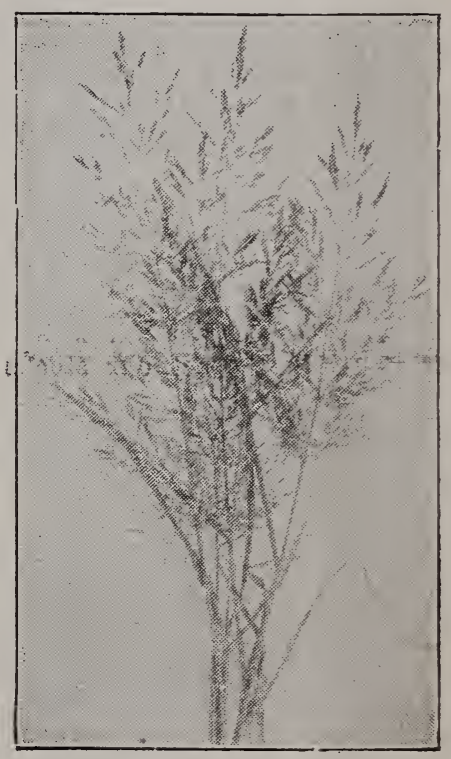

Italian Rye Grass 


\section{PLANET JR. NO. 4}

\section{COMBINED HILL AND DRILL SEEDER, WHEEL HOE, CULTIVATOR AND PLOW}

Holds 21/2 quarts. Steel driving wheel. Weight, complete, 50 lbs. Equipment: One pair of 6-inch hoes, three cultivator teeth, one garden plow, all oil tempered. One leaf guard, one marker.

PRICES-Seeder only, \$18.75; complete, $\$ 19.50$.

No. $4 \mathrm{D}$, as a seeder only, weight $40 \mathrm{lbs}$.

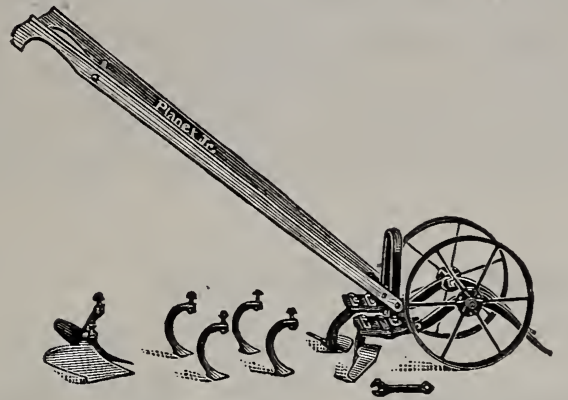

PLANET JR. NO. 25

The No. 4 Seeder is a special favorite; there are doubtless more of them in use in the world than any other seeder made. Gardeners and farmers having only a family garden who fear that they haven't quite enough work for a drill to do, will nevertheless find this combined tool will quickly pay for itself in labor saving and increased crops. With it one can do almost all the hoeing and general work in the garden, for it combines in one machine:

A capital hill-dropping seeder.

A continuous row seeder.

An admirable single wheel hoe.

A splendid single-wheel cultivator

An excellent furrower.

A rapid and efficient wheel garden plow.

Combined Hill and Drill Seeder, Double Wheel Hoe, Cultivator and Plow. Price \$20.00.

The new combined Garden Planter No. 25 is the latest improved and most complete tool of its kind. It is wholly without a rival in its line. It is thoroughly substantial and accurate in planting all kinds of seeds, either in hills or drilling. By detaching planting apparatus it makes a double wheel hoe, a cultivator or plow; 111/4-inch wheels. Holds $21 / 2$ quarts. Weight packed, 59 pounds. It combines in a most practical way the Planet Jr. No. 4 Drill and No. 12 Double Wheel Hoe.

Equipment: One pair of six-inch hoes, two pair of cultivator teeth, two plows, two leaf guards. Price \$26.50.

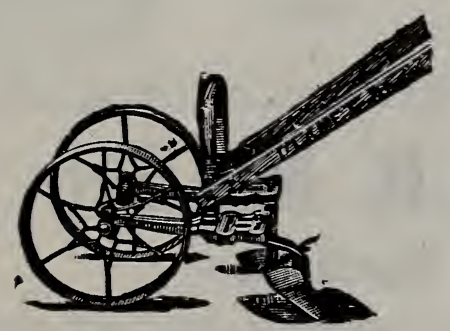

NO. 12 PLANET JR.

\section{DOUBLE WHEEL HOE}

Packed weight, $32 \mathrm{lbs}$.

Price, with attachment as in cut, $\$ 12.50$

One pair of 6 -inch hoes, two pairs of hollow steel cultirator teeth, one pair of plows, one pair of leaf lifters.

\section{No. 18 Planet Jr. Single Wheel Hoe}

This is the same style as our other single wheel hoes, and the plow, cultivator teeth or rakes may any of them be added to the equipment, although it is better and

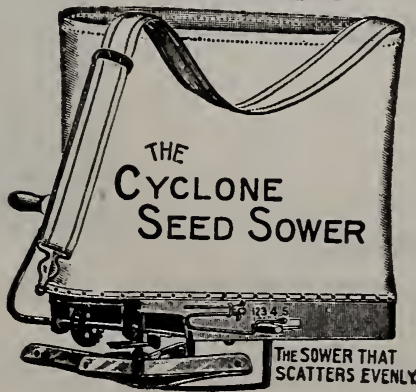
cheaper to select and secure what you need with the original purchase. Price as in cut, \$6.25. Packed, weight, 20 lbs.

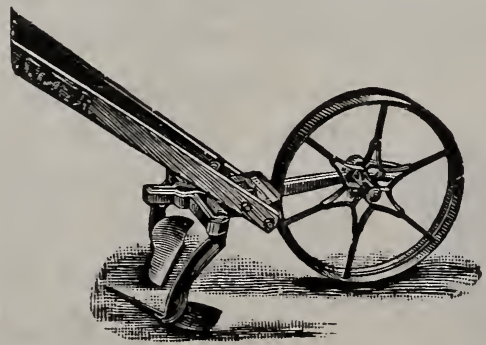

\section{CYCLONE SEEDER}

It is especially designed for distributing evenly all kinds of grain as well as every variety of grass seed. The constructio is simple, strong and practical. Price, \$1.50. Prices subject to change without notice. 


\section{BLATCHFOR

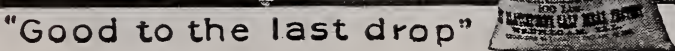

Sold in 100, 50 and 25 pound bags

\section{The Complete Milk-Equal}

Just the thing to raise your calves right from birth.

Then sell your milk and get the benefit of the high creamery prices.

No more scouring calves.

It is absolutely the only milk-substitute that contains all the elements necessary for rapid and healthy growth, and the only calf meal that is thoroughly cooked and prepared for digestion. Will push calves forward better and quicker than any other food.

100 pounds makes 100 gallons of Complete Milk-Substitute

\section{From Sow to Pasture}

Wean your little pigs easily, safely and

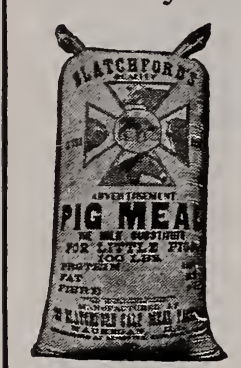

Sold in 100, 50 and $25 \mathrm{lb}$. bags cheaply on

\section{Blatchford's Pig Meal}

From Pig-hood to Pork-age it gives big bone and solid flesh. Prevents loss of growth and vitality during the critical weaning period, and always

makes the runts catch up.
Blatchford's "Fill the Esténg Mash fed to your pullets when three months old, will make early layers and keep them in perfect health. Does not force or fatten. Feed it to all your hens.

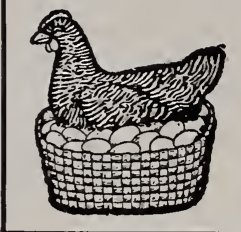

Make your eǵg profits sure

\section{BLATCHFORD'S MILK MASH Saves Your Baby Chicks and Ducklings}

Contains just the right combination of milk, milk-substitutes, meat and grains necessary for the best results.

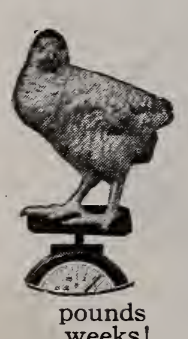

weeks!

Prevents bowel trouble, leg weakness and white diarrhea. It should be every chick's first feed! It carries them safely through the dangerous first three months. Raises $95 \%$ of every hatch!

Five pounds per chick will do it.

$$
\text { Grows-Matures-Fattens }
$$

Sold in 100 and 25 pound bags and in 4 pound trial cartons

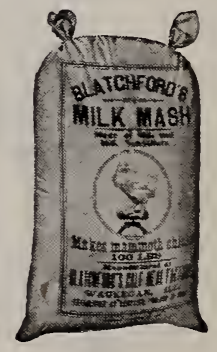

Larger and quicker profits to the farmers, stock-raisers and poultrymen are the real reasons for the success of hford Milk-Substitutes. Satisfied customers have been the cause of the steady annual increase in the Blatchford or over thirty-five years in the United States.

ecommend all of the Blatchford products, including special milk-substitutes for colts and for lambs. Write for prices. 


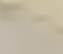

$4+5$ 


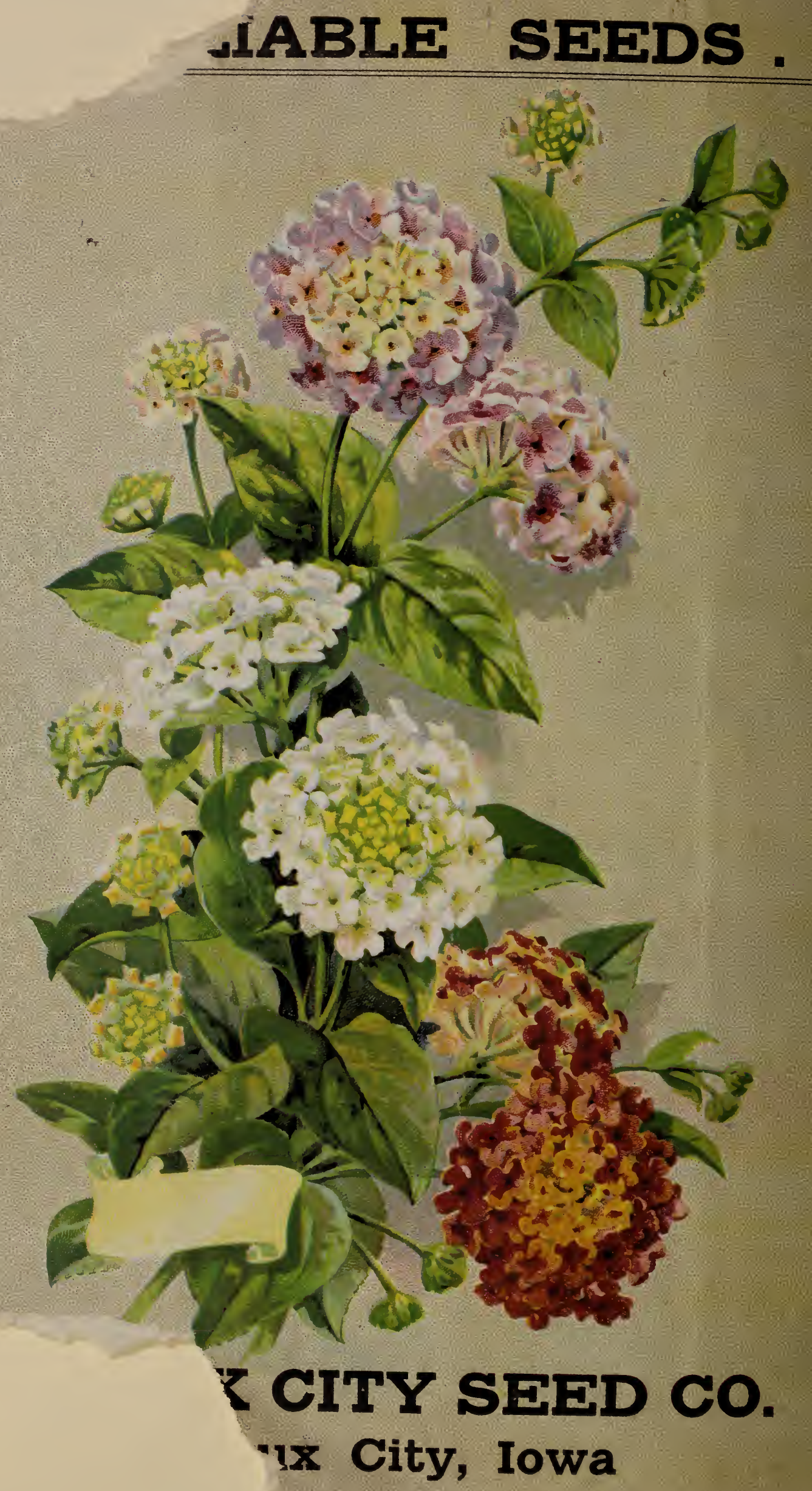

